\title{
Pathways of carbon oxidation in continental margin sediments off central Chile
}

\author{
Bo Thamdrup and Donald E. Canfield ${ }^{1}$ \\ Max Planck Institute for Marine Microbiology, Celsiusstr. 1, D-28359 Bremen, Germany
}

\begin{abstract}
Rates and oxidative pathways of organic carbon mineralization were determined in sediments at six stations on the shelf and slope off Concepción Bay at $36.5^{\circ} \mathrm{S}$. The depth distribution of C oxidation rates was determined to $10 \mathrm{~cm}$ from accumulation of dissolved inorganic $\mathrm{C}$ in 1-5-d incubations. Pathways of $\mathrm{C}$ oxidation were inferred from the depth distributions of the potential oxidants $\left(\mathrm{O}_{2}, \mathrm{NO}_{3}{ }^{-}\right.$, and oxides of $\mathrm{Mn}$ and $\left.\mathrm{Fe}\right)$ and from directly determined rates of $\mathrm{SO}_{4}{ }^{2-}$ reduction. The study area is characterized by intense seasonal upwelling, and during sampling in late summer the bottom water over the shelf was rich in $\mathrm{NO}_{3}{ }^{-}$and depleted of $\mathrm{O}_{2}$. Sediments at the four shelf stations were covered by mats of filamentous bacteria of the genera Thioploca and Beggiatoa. Carbon oxidation rates at these sites were extremely high near the sediment surface $\left(>3 \mu \mathrm{mol} \mathrm{cm}{ }^{-3} \mathrm{~d}^{-1}\right)$ and decreased exponentially with depth. The process was entirely coupled to $\mathrm{SO}_{4}{ }^{2-}$ reduction. At the two slope stations where bottom-water $\mathrm{O}_{2}$ was $>100 \mu \mathrm{M}, \mathrm{C}$ oxidation rates were 10-fold lower and varied less with depth; $\mathrm{C}$ oxidation coupled to the reduction of $\mathrm{O}_{2}, \mathrm{NO}_{3}{ }^{-}$, and $\mathrm{Mn}$ oxides combined to yield an estimated $15 \%$ of the total $\mathrm{C}$ oxidation between 0 and $10 \mathrm{~cm}$. Carbon oxidation through $\mathrm{Fe}$ reduction contributed a further $12-29 \%$ of the depth-integrated rate, while the remainder of $C$ oxidation was through $\mathrm{SO}_{4}{ }^{2-}$ reduction. The depth distribution of $\mathrm{Fe}$ reduction agreed well with the distribution of poorly crystalline $\mathrm{Fe}$ oxides, and as this pool decreased with depth, the importance of $\mathrm{SO}_{4}{ }^{2-}$ reduction increased. The results point to a general importance of $\mathrm{Fe}$ reduction in $\mathrm{C}$ oxidation in continental margin sediments. At the shelf stations, Fe reduction was mainly coupled to oxidation of reduced $\mathrm{S}$. These sediments were generally $\mathrm{H}_{2} \mathrm{~S}$-free despite high $\mathrm{SO}_{4}{ }^{2-}$ reduction rates, and precipitation of $\mathrm{Fe}$ sulfides dominated $\mathrm{H}_{2} \mathrm{~S}$ scavenging during the incubations. A large $\mathrm{NO}_{3}{ }^{-}$pool was associated with the Thioploca, and the shelf sediments were thus enriched in $\mathrm{NO}_{3}{ }^{-}$relative to the bottom water, with maximum concentrations of $3 \mu \mathrm{mol} \mathrm{cm}^{-3}$. The $\mathrm{NO}_{3}{ }^{-}$was consumed during our sediment incubations, but no effects on either $\mathrm{C}$ or $\mathrm{S}$ cycles could be discerned.
\end{abstract}

The mineralization of organic matter in the sea floor proceeds through a complex web of fermentative and respiratory microbial pathways where the oxidation of organic carbon to $\mathrm{CO}_{2}$ is balanced overall by concomitant reduction of the inorganic electron acceptors $\mathrm{O}_{2}, \mathrm{NO}_{3}{ }^{-}$, oxides of $\mathrm{Mn}$ and $\mathrm{Fe}$, and $\mathrm{SO}_{4}{ }^{2-}$. To understand the regulation of carbon oxidation, independent quantification of each pathway would be ideal, but such quantification is only possible for a few of the pathways. The radiotracer technique for measuring $\mathrm{SO}_{4}{ }^{2-}$ reduction rates (Jørgensen 1978) is one of the most robust methods available. Most importantly, $\mathrm{SO}_{4}{ }^{2-}$ reduction is an entirely biological process that uses only organic substrates (and $\mathrm{H}_{2}$ ) and has $\mathrm{H}_{2} \mathrm{~S}$ as the only immediate product. All of the other electron acceptors may be reduced in sediments either abiotically or through bacterial catalysis by one or more of the reduced inorganic species $\left(\mathrm{H}_{2} \mathrm{~S}, \mathrm{Fe}^{2+}, \mathrm{Mn}^{2+}\right.$,

${ }^{1}$ Present address: Institute of Biology, University of Odense, DK-5230 Odense M, Denmark.

\section{Acknowledgments}

We are grateful to Henrik Fossing, Victor Ariel Gallardo, and Bo Barker Jørgensen for initiating, organizing, and leading the Thioploca Expedition 1994 and to Kirsten Neumann and Swantje Fleischer for skillful technical assistance. We also thank the Captain and crew of RV Vidal Gormaz as well as all members of the scientific party for good company and collaboration during the expedition and for permission to cite unpublished results from the cruise. The comments of the reviewers are appreciated. or $\mathrm{NH}_{4}^{+}$), and no technique is available for measuring organotrophic respiration alone. Hence, the quantification of these processes relies on multilateral approaches wherein different types of measurements together constrain the rates.

Determinations of bacterial $\mathrm{SO}_{4}{ }^{2-}$ reduction rates in sediments are numerous and have shown that this pathway accounts for $10-90 \%$ of the $\mathrm{C}$ oxidation in coastal sediments, with $50 \%$ as a median valuc (Jørgensen 1982; Henrichs and Recburgh 1987; Canfield 1993). Most of the sulfide produced from $\mathrm{SO}_{4}{ }^{2-}$ reduction is typically reoxidized within the surface sediment rather than being buried. Thus, although benthic $\mathrm{O}_{2}$ uptake provides a good estimate of sediment metabolism in most continental margin sediments, a significant part of this $\mathrm{O}_{2}$ consumption is typically not directly coupled to $\mathrm{C}$ oxidation, but instead is coupled to the reoxidation of inorganic compounds such as $\mathrm{H}_{2} \mathrm{~S}$ (Jørgensen 1982). No technique is presently available for direct quantification of aerobic respiration in sediments.

Several methods have been used for measuring sedimentary $\mathrm{NO}_{3}{ }^{-}$reduction (Sørensen 1978; Seitzinger et al. 1984; Nielsen 1992), with results that generally demonstrate a minor role $(\leq 10 \%)$ for $C$ oxidation in coastal sediments (Sørensen et al. 1979; Canfield et al. 1993a). The significance for $\mathrm{C}$ oxidation may be higher in areas with low $\mathrm{O}_{2}$ and (or) elevated $\mathrm{NO}_{3}{ }^{-}$concentrations in the bottom water (cf. Canfield 1993).

The contributions of $\mathrm{Mn}$ and $\mathrm{Fe}$ reduction to $\mathrm{C}$ oxidation are the most infrequently quantified of the respi- 


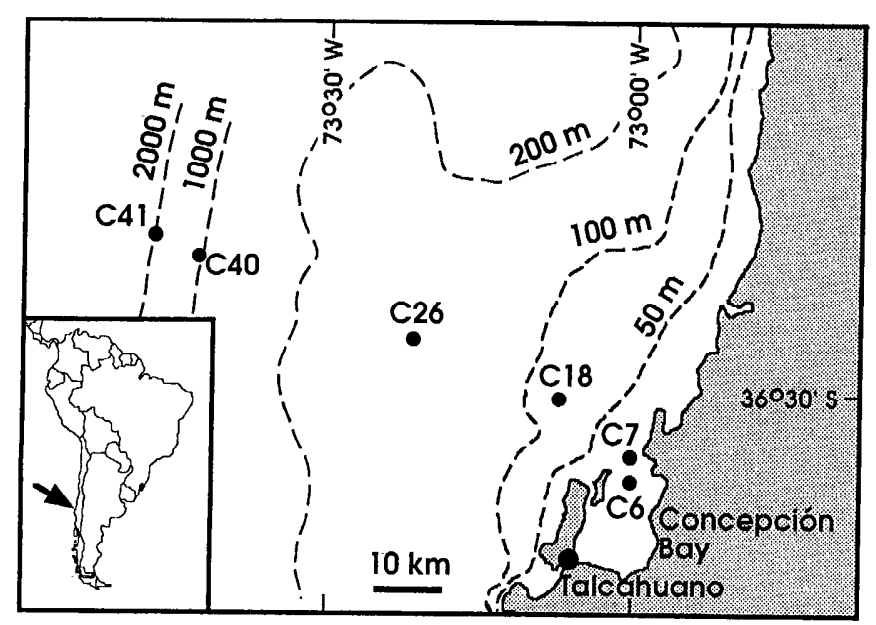

Fig. 1. Map showing sampling locations.

ratory types. Estimates based on pore-water gradients of $\mathrm{Mn}^{2+}$ and $\mathrm{Fe}^{2+}$ have found the processes to be of little importance (e.g. Bender and Heggie 1984; Reimers et al. 1992). In the presence of sediment and pore-water transport by bioturbation, however, such estimates underestimate actual turnover rates (Aller 1980; Canfield 1993), and a further complication arises from the adsorption or precipitation of reduced $\mathrm{Mn}$ and $\mathrm{Fe}$ (Canfield et al. 1993b; Thamdrup et al. 1994a). Indeed, Aller (1990) found that in Mn oxide-rich sediments of the Panama Basin, Mn reduction dominated $\mathrm{C}$ oxidation and that the process was supported by bioturbation, which mixed the oxides and organic matter into anoxic sediment layers.

A major difficulty in quantifying dissimilatory $\mathrm{Mn}$ and Fe reduction arises from the competing abiotic reactions with $\mathrm{H}_{2} \mathrm{~S}$ and, for $\mathrm{Mn}$ oxides, with $\mathrm{Fe}^{2+}$ (Pyzik and Sommer 1981; Postma 1985; Burdige and Nealson 1986). Reaction with $\mathrm{H}_{2} \mathrm{~S}$ may be so rapid that this compound may be undetectable even in sediments with high rates of $\mathrm{SO}_{4}{ }^{2-}$ reduction (Goldhaber and Kaplan 1974; Canfield et al. 1992). Reaction with $\mathrm{H}_{2} \mathrm{~S}$ was found to dominate $\mathrm{Fe}$ reduction in a coastal bay, with dissimilatory $\mathrm{Fe}$ reduction contributing $<5 \%$ to $\mathrm{C}$ oxidation (Thamdrup et al. 1994a). Similar conclusions have been reached for $\mathrm{Mn}$ reduction in a number of relatively $\mathrm{Mn}$-poor sediments (Canfield et al. 1993b; Aller 1994; Thamdrup et al. 1994a).

By contrast, Sørensen (1982) showed that in oxidized sediment, $\mathrm{Fe}$ reduction proceeded through biological catalysis and was independent of $\mathrm{SO}_{4}{ }^{2-}$ reduction. Furthermore, from the depth distribution of $\mathrm{O}_{2}, \mathrm{NO}_{3}{ }^{-}$, and rates of $\mathrm{SO}_{4}{ }^{2-}$ reduction in some coastal sediments, a zone dominated by Fe reduction has been suggested (Sørensen and Jørgensen 1987; Hines et al. 1991). In a study of three sites in the Norwegian Trough, Canfield et al. (1993b) compared total mineralization rates to $\mathrm{SO}_{4}{ }^{2-}$ reduction rates in anoxic sediment incubations. Bascd on excess total mineralization relative to the mineralization duc to $\mathrm{SO}_{4}{ }^{2-}$ reduction, $\mathrm{Fe}$ reduction was found to contribute 44 and $69 \%$ of anaerobic $\mathrm{C}$ oxidation at two sites, whereas at the third site, essentially all mineralization was coupled to $\mathrm{Mn}$ reduction. These large contributions
Table 1. Positions and bottom-water data for stations sampled 12-23 March 1995 (nd-not detected).

\begin{tabular}{lcrccc}
\hline \hline & $\begin{array}{c}\text { Position } \\
\left(36^{\circ} \mathrm{S}+, 7^{\circ} \mathrm{W}+\right)\end{array}$ & $\begin{array}{c}\text { Depth } \\
(\mathrm{m})\end{array}$ & $\begin{array}{c}\mathrm{Temp} \\
\left({ }^{\circ} \mathrm{C}\right)\end{array}$ & $\begin{array}{c}\mathrm{O}_{2}{ }^{*} \\
(\mu \mathrm{M})\end{array}$ & $\begin{array}{c}\mathrm{NO}^{-} \\
(\mu \mathrm{M})\end{array}$ \\
\hline $\mathrm{C} 6$ & $37.3^{\prime} \mathrm{S},\left(00.5^{\prime} \mathrm{W}\right.$ & 34 & 11.4 & nd & 3 \\
$\mathrm{C} 7$ & $36.5^{\prime} \mathrm{S}, 00.6^{\prime} \mathrm{W}$ & 37 & 11.6 & nd & 21 \\
$\mathrm{C} 18$ & $30.8^{\prime} \mathrm{S},() 7.7^{\prime} \mathrm{W}$ & 87 & 11.7 & nd & 18 \\
$\mathrm{C} 26$ & $25.9^{\prime} \mathrm{S}, 23.4^{\prime} \mathrm{W}$ & 122 & 11.2 & nd & 15 \\
$\mathrm{C} 40$ & $20.1^{\prime} \mathrm{S}, 43.7^{\prime} \mathrm{W}$ & 1,015 & 6.0 & 105 & 43 \\
$\mathrm{C} 41$ & $19.6^{\prime} \mathrm{S}, 49.3^{\prime} \mathrm{W}$ & 2,000 & 3.9 & 220 & 35 \\
\hline
\end{tabular}

* Data provided by J. K. Gundersen and R. N. Glud.

were associated with strong bioturbation and, in the last case, with a very high Mn oxide content. From comparison with benthic $\mathrm{O}_{2}$ uptake rates, it was concluded that the anaerobic processes dominated $\mathrm{C}$ oxidation, whereas aerobic respiration contributed only 4-17\%; furthermore, it was suggested that the role of aerobic respiration in $\mathrm{C}$ oxidation has generally been overestimated in continental margin sediments (Canfield et al. 1993a).

Although the studies cited above have provided the first evidence on the diversity of $\mathrm{C}$ oxidation pathways, it is also clear that a general understanding of the relative importance of these pathways and their regulation in sediments has not been reached. We have applied an approach similar to that of Canficld et al. (1993b) to sediments from the upwelling region off central Chile. Stations were chosen on a transect that ran from a highly productive shelf area with $\mathrm{O}_{2}$-deficient bottom waters to halfway down the continental slope. This approach gave us an opportunity to study how the pathways of $\mathrm{C}$ oxidation responded to variations in bottom-water $\mathrm{O}_{2}$ levels. This study extended the small database on the significance of dissimilatory $\mathrm{Fe}$ and $\mathrm{Mn}$ reduction and also served as a further test of the methodology.

\section{Study area}

As part of the "Thioploca Cruise 1994" onboard RV Vidal Gormaz (Fossing et al. 1995), sediments were collected on the cortinental margin off Concepción Bay (Fig. 1, Table 1). Stations were distributed along a transect from the mouth of the Bay at 34-m depth, across the 40$\mathrm{km}$-wide shelf, to 2,000-m depth on the slopc. The region is characterized by a very high upwelling-driven primary production during summer (September-April), with upwelling induced by south-southwest winds that typically blow for periods of a week, followed by a few days of calm or north winds (Ahumada et al. 1983; Arcos and Wilson 1984; Peterson et al. 1988). The noncontinuous upwelling pattern causes strong temporal variations in primary productivity. Sediments were sampled during late summer (12-23 March), and upwelling-favorable winds blew throughout the first half of March.

A pronounced $\mathrm{O}_{2}$ minimum zone is associated with the south-flowing equatorial subsurface water, which is found at 100-400-m depth in nonupwelling periods (Brandhorst 1959; see Sobarzo 1994). During summer upwelling, this 
water mass may reach $20-\mathrm{m}$ depth and may cover the shelf and reach into the Concepción Bay, thereby reducing bottom-water $\mathrm{O}_{2}$ concentrations over the shelf (Ahumada et al. 1983; Peterson et al. 1988). Thus, $\mathrm{O}_{2}$ concentrations $<11 \mu \mathrm{M}$ have been reported from the shelf bottom water during this season (Roa et al. 1995). Inside the bay, bottom-water anoxia, $\mathrm{H}_{2} \mathrm{~S}$ relcase, and faunal mass mortality are recurring phenomenona (Ahumada et al. 1983). During the sampling period, an $\mathrm{O}_{2}$-deficient zone was found at 100-300-m depth offshore, and it stretched up over the shelf to $30-40-\mathrm{m}$ depth, so that all shelf sediments studied were fully anoxic (Table 1; R. N. Glud et al. in prep.).

Sedimentation rates from ${ }^{210} \mathrm{~Pb}$ distributions at stations C41, C40, C18 (Fig. 1), and at locations close to C6 and $\mathrm{C} 7$, all fall in the range $1-2.2 \mathrm{~mm} \mathrm{yr}^{-1}$ (mean, 1.2; $\mathrm{M}$. Salamanca pers. comm.). Giant filamentous bacteria of the genus Thioploca were first described from the shelf sediments outside the bay, where they occur in matlike masses in the $\mathrm{O}_{2}$ minimum zone (Gallardo 1977). On the inner shelf, where $\mathrm{O}_{2}$ levels vary strongly over the year, the mats proliferate in summer and may break up and become exported with bottom currents during winter (V. A. Gallardo pers. comm.). Single filaments are up to 40 $\mu \mathrm{m}$ wide and $7 \mathrm{~cm}$ long (Fossing et al. 1995) and are found in conspicuous (up to 1.5 -mm-thick) sheathed bundles. These filaments belong to the species Thioploca chilea and Thioploca araucae (Maier and Gallardo 1984a; Teske et al. 1996). Sulfide oxidation has been proposed as their main method of metabolism (Maier and Gallardo $1984 b$ ), but despite wide distribution of these species in the Chilean and Peruvian upwelling areas (Gallardo 1977), their ecology is poorly known and was a main subject of investigation during the cruise (Fossing et al. 1995).

\section{Methods}

The sediments were sampled with a multiple corer (Barnett et al. 1984) that retrieved up to eight cores in polycarbonate liners of $9.6-\mathrm{cm}$ i.d, although for stations C7 and C40, a $30 \times 30-\mathrm{cm}$ box core was subsampled into such liners on deck. Cores were only accepted when the surface appeared neither affected by resuspension nor, in presence of surface mats, disrupted or pushed down during coring. Cores were immediately transferred to an incubator set at bottom-water temperature (Table 1).

Sediment incubation and pore-water extraction-For the pore-water chemistry, one or two cores were processed, generally within $1 \mathrm{~h}$ of retricval. In an $\mathrm{N}_{2}$-filled glove bag, the sediment was sectioned in appropriate intervals and loaded into polypropylenc centrifuge tubes. The tubes were tightly capped and centrifuged for 5-10 $\mathrm{min}$, and after reintroduction in to the glove bag, the pore water was sampled and filtered through Whatman GF/F glass-fiber filters. Conservation and analyses of samples are described below.

A finer spatial resolution of the $\mathrm{NO}_{3}{ }^{-}$distribution near the sediment surface was attempted with a whole-core squeezer (Bender et al. 1987). Pore water was extruded by driving the sediment core from below toward a stationary lid with a central $1-\mathrm{mm}$-wide hole covered with a paper filter. Water was collected in 2-ml aliquots, each corresponding to $\sim 0.9-\mathrm{mm}$ depth in the core, depending on porosities.

For the determination of carbon mincralization rates and pathways, sediment from the upper $10 \mathrm{~cm}$ of six cores (434 $\mathrm{cm}^{2}$ in total) was incubated as described by Canfield et al. (1993b) in laminated ethyl-vinyl-alcohol plastic Würgler bags (Ril-O-Ten; Hansen 1992; Kruse 1993) after it had been sectioned into eight depth intervals and the parallel intervals from different cores were mixed. Sediments were processed over $\sim 2 \mathrm{~h}$ in an $\mathrm{N}_{2}$-filled glove bag beginning within $4 \mathrm{~h}$ of retrieval. The incubation bags were first closed with a big clip, which eliminated any head space, and they were then heat-sealed behind the clip, thus avoiding heating of the sediment. The bags were incubated dry at bottom-water temperature (Table 1) and, in addition to the initial sample, sampled four times at regular intervals in the glove bag. Apart from the initial exposure during loading, the bags werc exposed to room temperature $\left(\sim 18^{\circ} \mathrm{C}\right)$ for $<10$ min during samplings to avoid temperature artifacts on rates. The generally linear accumulation of metabolites during our incubations argues against any significant transient stimulation of metabolic activity resulting from initial samplc heating and handling. During incubation, the bags were not placed in a larger $\mathrm{N}_{2}$-filled bag as practiced by Canficld ct al. (1993b). The range of oxygen permeability reported for the plastic (Hansen 1992; Kruse 1993) at a maximum bag surface: volume ratio of $0.2 \mathrm{~m}^{2}$ liter $^{-1}$ corresponds to an oxygen input of $1-4 \mathrm{nmol} \mathrm{cm} \mathrm{cm}^{-3} \mathrm{~d}^{-1}$, which is insignificant for the metabolically active sediments studied here. Generally, however, we recommend the use of an outer anoxic bag for sediment incubations.

For stations C7-C26, the total incubation time was 30$35 \mathrm{~h}$; station $\mathrm{C} 40$ was incubated for $4 \mathrm{~d}$ and $\mathrm{C} 41$ for $5 \mathrm{~d}$. At station C6, the incubation was ended after the second sampling (5-h incubation) because of incubator failure. With stations $\mathrm{C} 7$ and $\mathrm{C} 18$, we prolonged the incubations to 6 and $10 \mathrm{~d}$, respectively, to monitor long-term changes in the pore water and solid phases. For each sampling, sediment was loaded into centrifuge tubes and pore water was retrieved under $\mathrm{N}_{2}$ as described above.

During the short-term incubations, rates of sulfate reduction were determined once at $\mathrm{C} 6$ and $\mathrm{C} 7$ and twice at all other sites in splits of $10-\mathrm{ml}$ sediment with ${ }^{35} \mathrm{SO}_{4}{ }^{2-}$ tracer (Jørgensen 1978) in 3-h (shelf sites) to 10-h (C41) incubations at the same temperature as the bags. For termination, the sediment was fixed in $20 \%$ zinc acetate and frozen. The reduced ${ }^{35} \mathrm{~S}$ was recovered by distillation with boiling acidic $\mathrm{Cr}^{2+}$ solution (Zhabina and Volkov 1978; Canfield et al. 1986; Fossing and Jørgensen 1989).

At the end of the short-term incubations, pore-water $\mathrm{pH}$ was determined with a glass electrode that was inserted into subsamples of the sediment and was calibrated with NBS standards.

Pore-water analyses - Portions of pore water for $\mathrm{\Sigma CO}_{2}$ (dissolved inorganic carbon) and $\mathrm{NH}_{4}{ }^{+}$analyses were filtered into $1.8-\mathrm{ml}$ glass vials that were capped with Teflon- 
coated butyl rubber septa, leaving no gas phase and maintaining anoxia. The samples were stored at $4^{\circ} \mathrm{C}$ and analyzed right after termination of the short-term incubations or, for the pore-water cores, within $5 \mathrm{~d}$ by means of flow-injection systems with gas-cxchange and conductivity detection for both species (Hall and Aller 1992; SD $2 \%$ for both). Although we cannot exclude slight $\Sigma \mathrm{CO}_{2}$ production from DOC oxidation during the brief storage, we expect this to be insignificant relative to the production in the sediments given the storage conditions. Samples that contained $\mathrm{H}_{2} \mathrm{~S}$ from $\mathrm{C} 6$ and samples from prolonged incubations at $\mathrm{C} 7$ and $\mathrm{C} 18$ that contained $\mathrm{H}_{2} \mathrm{~S}$ were first analyzed for $\mathrm{NH}_{4}{ }^{+}$and then treated with $5 \%$ vol of a $10 \% \mathrm{H}_{2} \mathrm{O}_{2}$ solution (R. C. Aller pers. comm.). This treatment removed all $\mathrm{H}_{2} \mathrm{~S}$ within $10 \mathrm{~min}$ and had no effect on $\mathrm{SCO}_{2}$ measurements, as determined from similarly treated standards.

Pore water for determination of $\mathrm{NO}_{3}{ }^{-}+\mathrm{NO}_{2}{ }^{-}$was stored frozen. For analysis, $\mathrm{NO}_{3}{ }^{-}$was reduced to $\mathrm{NO}_{2}{ }^{-}$ by shaking the sample with spongy cadmium, and total $\mathrm{NO}_{2}^{-}$was subsequently determined (Jones 1984). Tests showed that $3 \mathrm{~h}$ of reaction ensured complete reduction to $\mathrm{NO}_{2}{ }^{-}$without overreduction to $\mathrm{NH}_{4}{ }^{+}$.

Dissolved $\mathrm{Fe}^{2+}$ in the pore-water cores was determined immediately after filtration by colorimetry with a Ferrozine solution without reducing agent (det. limit $1 \mu \mathrm{M}$; SD 2\%; Stookey 1970), whereas pore-water $\mathrm{Fe}^{2+}$ in the incubated sediment was determined in acidified samples at the end of the incubation. Dissolved $\mathrm{Mn}^{2+}$ and $\mathrm{Ca}^{2+}$ were analyzed in acidified porc water by flame atomic absorption spectroscopy $\left(\mathrm{Mn}^{2+}\right.$ det. limit $0.5 \mu \mathrm{M}$; SD $2 \%$ for both).

Sulfate was determined by nonsuppressed anion chromatography (SD 1\%). Samples for $\mathrm{H}_{2} \mathrm{~S}$ analysis (100-300 $\mu \mathrm{l})$ were fixed immediatcly in $50 \mu \mathrm{l} 20 \% \mathrm{Zn}$ acctate and frozen for later analysis by the methylene blue method (det. limit $1 \mu \mathrm{M}$; SD 5\%; Cline 1969).

Solid-phase analysis-Portions of sediment from the beginning of the incubations and the sediment remaining in the bags at the end were sampled under $\mathrm{N}_{2}$, frozen, and later analyzed for solid $\mathrm{Fe}, \mathrm{Mn}$, and $\mathrm{S}$ phases. Iron was extracted with dithionite-citrate-acctic acid (DCA; pH 4.8; Lord 1980; Canficld 1989) and acidic ammonium oxalate (pH 3.0; Schwertmann 1964). DCA extracts all free iron oxides (except some magnetite; Canficld 1988; 1989) together with $\mathrm{Fe}(\mathrm{II})$ phases such as $\mathrm{FeS}$ and $\mathrm{FeCO}_{3}$ (Thamdrup et al. 1994a; Kostka and Luther 1994) but does not allow a separatc detcrmination of Fe(III) and $\mathrm{Fe}(\mathrm{II})$. Oxalate has been used to extract poorly crystalline Fe oxides from soils and sediments (Schwertmann 1964; Canfield 1988, 1989). Its sclectivity is, however, dependent on the absence of $\mathrm{Fe}^{2+}$, because the $\mathrm{Fe}^{2+}$-oxalate complex efficiently catalyzes the dissolution of crystalline Fe(III) phases (Fischer 1973; Suter et al. 1988). Because ferrous phases such as $\mathrm{FeS}$ and $\mathrm{FeCO}_{3}$ are also dissolved by this extraction, unwanted dissolution of unreactive Fe(III) phases from anoxic Fe(II)-bcaring sediments results (Thamdrup et al. 1994a; Kostka and Luther 1994). To avoid this catalytic interference of $\mathrm{Fe}^{2+}$, we air-dried the sediment before extraction, thercby oxidizing FeS and $\mathrm{FeCO}_{3}$ to ferrihydrite (Canfield 1988, 1989; Raiswell et al. 1994). Calibiation experiments with pure Fe phases mixed into dried sediment confirmed the selectivity towards poorly cry'stalline oxides (D. E. Canficld unpubl.). In parallel with the (oxic) extraction of dried sediment, $\mathrm{Fe}^{2+}$ was determined in an anoxic oxalate extraction of fresh (frozen) sediment (Phillips and Lovley 1987) in order to quantify the contribution of $\mathrm{Fe}$ (II) phases to the oxalate-extractable Fe. Oxalate-extractable Fe(III) was defined as the difference between these two measures.

We used 10-ml extractants with $\sim 150 \mathrm{mg}$ wet or 50 $\mathrm{mg}$ of dry sediment. Extraction times were $1 \mathrm{~h}$ for DCA and $4 \mathrm{~h}$ for oxalate, and the extraction conditions were otherwise as described by Canfield et al. (1993b) and Thamdrup et al. (1994a). Total extractable Fe and Fe(II) were determinec. with Ferrozine (above references). Manganese was determined in the DCA extracts by flame AAS.

Acid-volatile sulfide (AVS $=\mathrm{FeS}+\mathrm{H}_{2} \mathrm{~S}$ ) and chromium-reducible sulfur $\left(\mathrm{CRS}=\mathrm{FeS}_{2}+\mathrm{S}^{0}\right.$ ) were determined after a two-step distillation with cold $2 \mathrm{~N} \mathrm{HCl}$ and boiling 0.5 $\mathrm{M} \mathrm{Cr}^{2+}$ solution (Fossing and Jørgensen 1989). Elemental sulfur was extracted by shaking the samples with methanol for $24 \mathrm{~h}$ and was then determined with HPLC (T. G. Ferdelman et al. unpubl.). For this determination, sediment fixed with $\mathrm{Zn}$ acetate from the $\mathrm{SO}_{4}{ }^{2-}$ reduction measurements was used. Concentrations of FeS and $\mathrm{FeS}_{2}$ were calculated as AVS $-\mathrm{H}_{2} \mathrm{~S}$ and $\left(\mathrm{CRS}-\mathrm{S}^{\circ}\right) /$ 2 , respectively.

Organic $\mathrm{C}$ and total $\mathrm{N}$ and $\mathrm{S}$ were determined in dried sediment on an clemental analyzer (Carlo Erba; SD 2\%); inorganic $\mathrm{C}$ was removed by acidification $(\mathrm{HCl})$ and drying of the sample boats prior to analysis. Inorganic $\mathrm{C}$ in carbonates was determined by acidification of $0.1-0.5 \mathrm{~g}$ of dried sediment with $10 \mathrm{ml}$ of $4 \mathrm{M} \mathrm{HCl}$ in $120-\mathrm{ml}$ serum bottles and measurement of the evolved $\mathrm{CO}_{2}$ in the headspace by gas chromatography with thermal conductivity detection (SD 5\%). These values were corrected for carbonate alkalinity.

Thioploca analysis and $\mathrm{NO}_{3}-$ extractions-For determination of the bulk composition of Thioploca, a $10-\mathrm{cm}-$ deep sediment core with a well-developed mat at the surface was sicved $(1 \mathrm{~mm})$ and washed with surface seawater. Remainitig detritus and macrofauna were removed with forccps, leaving a visually clean pellet of sheathed Thioploca, which was then frozen. About $1 \mathrm{~g}$ wet wt of Thioploca was ireeze-dried and ground for analysis. Organic $\mathrm{C}, \mathrm{N}$, and $\mathrm{S}$ were determined with an elemental analyzer as above. The $\mathrm{NO}_{3}^{-}$content was analyzed as described below. To estimate the contribution of salt to the dry weight, $\mathrm{Cl}^{-}$was extracted in water and analyzed by ion chromatography. The total salt content was calculated from $\mathrm{Cl}^{-}$and the typical composition of seawater.

Because we discovered during the cruise that Thioploca concentrated $\mathrm{NO}_{3}{ }^{-}$far beyond pore-water concentrations, an $\mathrm{NO}_{3}{ }^{-}$extraction of total sediment was tested and applied. Drying and rewetting had proven to be an efficient way to release $\mathrm{NO}_{3}{ }^{-}$from single filaments of 


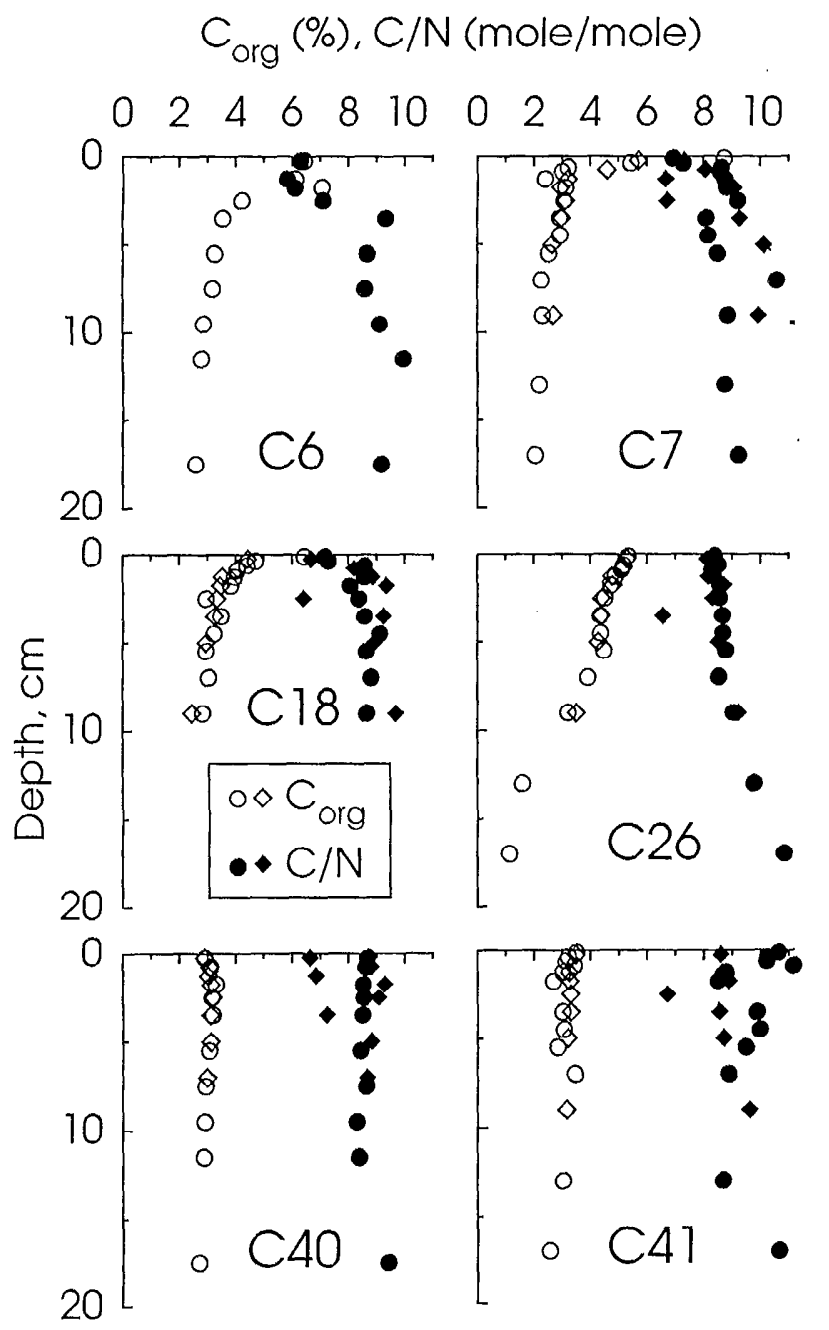

Fig. 2. Depth distributions of organic carbon and $\mathrm{C}_{\text {org }}: \mathrm{N}$ ratios. Data both from sediment used for incubations (diamonds) and from a core for pore-water analysis (circles) are shown.

Thioploca (L. P. Nielsen pers. comm.). For the extraction, frozen sediment was dried either at $80^{\circ} \mathrm{C}$ after brief thawing or in a freeze-drier that avoided thawing completely. The sediment was ground by hand and $50-100 \mathrm{mg}(5 \mathrm{mg}$ for Thioploca samples) was then extracted in $10 \mathrm{ml}$ water for $15 \mathrm{~min}$. After centrifugation, $\mathrm{NO}_{3}{ }^{-}$in the supernatant was determined as in the pore-water samples. The extraction procedure was tested with surface sediment from the $\mathrm{NO}_{3}{ }^{-}$rich $\mathrm{C} 7$. Large and highly reproducible amounts of $\mathrm{NO}_{3}{ }^{-}$were released in the first 15 -min extraction, and the yield decreased sharply in a second wash. The relcase of $\mathrm{NO}_{3}{ }^{-}$decreased little in three further washes and stabilized at concentrations $\sim 0.2 \mu \mathrm{mol} \mathrm{g}^{-1}$, corresponding to $1-2 \mu \mathrm{M}$ in the extract independent of the yicld in the first wash. Extraction in $1 \mathrm{M} \mathrm{KCl}$ or sonication during the extraction did not increase the yield (data not shown). Also, extraction of the decpest sediment sections and of scdiment from the prolonged incubations, where strongly reducing conditions developed, consistently yielded nonzero $\mathrm{NO}_{3}-$ concentrations around the "background" level of the test extractions (see below). We interpret this stable background concentration as an artifact for which we have no certain explanation, but which could be the result of nitrification during the extraction. This background was subtracted in calculations of $\mathrm{NO}_{3}{ }^{-}$pool sizes.

\section{Results}

Sediment description - White filamentous bacteria (Thioploca spp. and Beggialoa spp.) were observed in masses in the anoxic shelf sediments and in mats formed on the surface. The sediment at station C6 was black and sulfidic and had a web of Beggiatoa filaments practically floating on $2 \mathrm{~cm}$ of fluff that graded into silt. At C7 and C18, 2-cm-thick matlike structures containing Thioploca, the small suspension feeding polychaete Paraprionospio pinnata $(\sim 1 \mathrm{~cm})$, and juvenile squat lobsters, Pleuroncodes monodon $(\sim 1 \mathrm{~cm})$ were observed on the surface of the otherwise silty, dark brown sediments. Single strands of Thioploca and a few burrows of larger polychactes were seen to $10-\mathrm{cm}$ depth. Station $\mathrm{C} 26$ did not have a distinct bacterial mat at the surface, but strands of Thioploca were distributed within the upper $10 \mathrm{~cm}$. This sediment consisted of green silt to $10-15-\mathrm{cm}$ depth and gray clay with a purple tinge below this level. At the slope stations, the sediment was brown and silty and infauna was indicated by burrow structures.

Solid phase and pore-water chemistry - To facilitate direct comparison of rates and pool sizes, concentrations of solids (except $\mathrm{C}_{\text {org }}$ and $\mathrm{N}$ ) are given on a volume rather than on a dry weight basis. To some extent, this choice masks changes that occur within the solids, because a component that makes up a constant fraction of the solids incrcases with depth solely owing to compaction. This masking effect is particularly significant at the inner sites, where porosities decreased from $>0.95$ in the surface mat to $\sim 0.85$ at $10-\mathrm{cm}$ depth.

The distribution of the organic $\mathrm{C}$ and the $\mathrm{C}_{\mathrm{org}}: \mathrm{N}$ ratio in the sediments are shown in Fig. 2. Only the surface layers showed pronounced changes through the transect, with high $\mathrm{C}_{\text {org }}$ concentrations of up to $8 \%$ dry wt at the shallower stations decreasing to $\sim 3 \%$ at the slope stations. A concentration $\sim 3 \%$ was also approached in the deeper parts of the shelf cores. At $\mathrm{C} 26, \mathrm{C}_{\text {org }}$ was $\sim 4 \%$ in the upper $10 \mathrm{~cm}$ and dropped to $1 \%$ below this. This change coincided with the abrupt color change from green to gray. The station also stood out with respect to other solid components (see below). Low $\mathrm{C}_{\mathrm{org}}$ : $\mathrm{N}$ ratios of 6-7 were associated with the high $\mathrm{C}_{\text {org }}$ in the mats; otherwise, values were $\sim 9$.

The distribution of inorganic carbon $\left(\mathrm{\Sigma CO}_{2}\right)$ and $\mathrm{NH}_{4}{ }^{+}$ in the pore waters showed a uniform trend along the transect, and the extremely stecp concentration gradients and strong convex curvature of the profiles at the nearshore stations indicated high rates of $\mathrm{C}$ mineralization (Fig. 3). Offshore, both the surface gradients and the curvature of the concentration profiles decreased dramatically. The $\Sigma \mathrm{CO}_{2}$ and $\mathrm{NH}_{4}{ }^{+}$distributions were generally parallel. At $\mathrm{C} 7$ and in one core at $\mathrm{C} 18$, however, a preferential release of $\mathrm{NH}_{4}{ }^{+}$was indicated near the surface. 


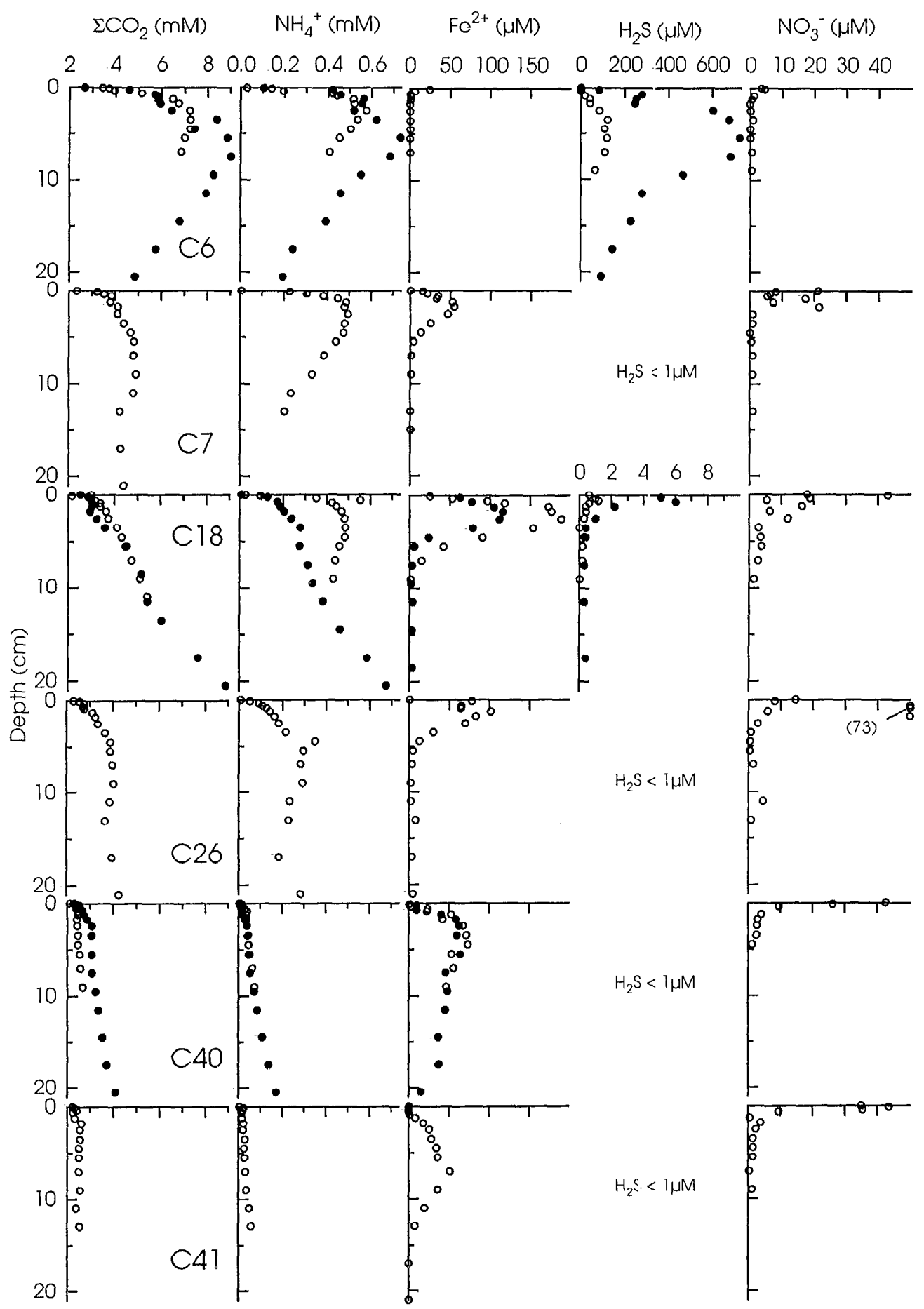

Fig. 3. Depth distributions of dissolved species from the shallowest (C6, top) to the deepest (C41, bottom) site. At stations C6, C18, and C40, two cores wer? analyzed, which are distinguished by the use of open and filled circles.

Potential oxidants for $\mathrm{C}_{\text {org }} \cdot \mathrm{O}_{2}$ and $\mathrm{NO}_{3}{ }^{-}$- Bottom-water oxygen was available only on the slope, where it penetrated into the sediment to $6 \mathrm{~mm}$ at $\mathrm{C} 40$ and to $8 \mathrm{~mm}$ at C41 (Table 1; J. K. Gundersen and R. N. Glud pers. comm.). The penetration for $\mathrm{C} 40$ was obtained in situ with oxygen slectrodes mounted on a benthic lander (Gundersen and Jørgensen 1991) and that for C41 was measured in a core incubated at bottom-water temperature and $\mathrm{O}_{2}$ concentration onboard ship (Glud et al. 1994).

Nitrate was $\geq 15 \mu \mathrm{M}$ in the bottom water at all stations 


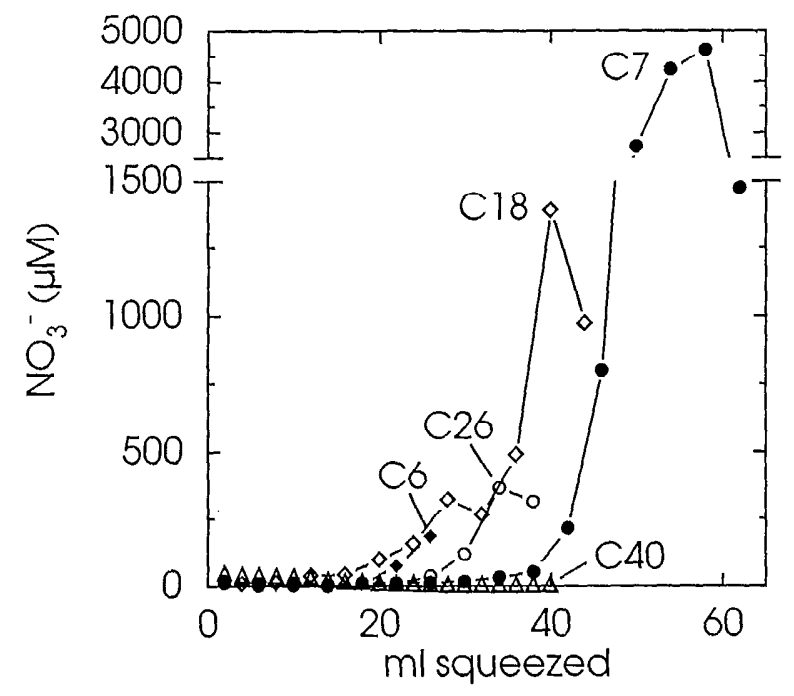

Fig. 4. Nitrate concentration in fractions collected from whole-core squeezing of sediment from five stations. Two milliliters corresponds to $\sim 0.9-\mathrm{mm}$ depth in the core.

except $\mathrm{C} 6$ (Table 1). As defined from centrifuged sediment, pore-water $\mathrm{NO}_{3}{ }^{-}$penctrated to $5 \mathrm{~mm}$ at $\mathrm{C} 6,1.5-$ $2 \mathrm{~cm}$ at the other shelf stations, and to $1 \mathrm{~cm}$ on the slope (Fig. 3). For the shelf stations (C7-C26), $\mathrm{NO}_{3}{ }^{-}$profiles were characterized by an irregular shape and by several values well above the bottom-water concentration. Attempts to obtain profiles at a finer spatial resolution by means of a whole-core squeezer, which has been used successfully for $\mathrm{NO}_{3}-$ with other sediments (Bender et al. 1987; Brandes and Devol 1995), produced even stranger results. We observed that the concentration of $\mathrm{NO}_{3}{ }^{-}$in the collected pore water increased with virtual depth as the squeezing proceeded and more pressure was applicd, reaching up to $5 \mathrm{mM}$ (Fig. 4). Such effects were not observed with the slope sediments. Analysis of single filaments of Thioploca showed that these bacteria may concentrate $\mathrm{NO}_{3}$ - in their large central vacuole (Fossing et al. 1995); therefore, centrifuging pore water or squeezing sediment may lead to elevated porc-water $\mathrm{NO}_{3}{ }^{-}$concentrations by disrupting cells.

In Table 2, the total amount of $\mathrm{NO}_{3}{ }^{-}$released from the sediments by whole-core squeezing is compared to that measured in the pore water after centrifugation. For C6-C18 the whole-core-squeezed sediment contained far more $\mathrm{NO}_{3}{ }^{-}$than did the centrifuged pore water, but we were not certain that most $\mathrm{NO}_{3}{ }^{-}$in the sediment was even released by the whole-core squeezing. As an alternative estimate of the sediment $\mathrm{NO}_{3}{ }^{-}$pool, we therefore extracted $\mathrm{NO}_{3}{ }^{-}$from dried sediment. The depth distribution of extractable $\mathrm{NO}_{3}{ }^{-}$(Fig. 5) confirmed that at the Thioploca mat stations $\mathrm{C} 18$ and in particular C7, much more $\mathrm{NO}_{3}{ }^{-}$was present in the sediment than was measured in the pore water (Table 2). Although the pool of extractable $\mathrm{NO}_{3}{ }^{-}$was 5 times larger than the pore-water pool at these stations, it still represented only half the pool extruded by whole-core squeezing. It was surprising that whole-core squeezing provided the highest estimates
Table 2. $\mathrm{NO}_{3}{ }^{-}$pool size measured with different methods $\left(\mathrm{mmol} \mathrm{m}{ }^{-2}\right)$ (nd-not detcctcd; nm-not measured).

\begin{tabular}{lccc}
\hline & $\begin{array}{c}\text { Pore-water } \\
\text { centrifugation }\end{array}$ & $\begin{array}{c}\text { Whole-core } \\
\text { squeezing }\end{array}$ & $\begin{array}{c}\text { Drying and } \\
\text { extraction }\end{array}$ \\
\hline C6 & 0.1 & 1.6 & 0.3 \\
C7 & 0.3 & 26.9 & 16.9 \\
C18 & 0.6 & 7.2 & 3.3 \\
C26 & 0.8 & 0.6 & 1.7 \\
C40 & 0.2 & 0.3 & $\mathrm{~nm}$ \\
C41 & 0.3 & 0.2 & $\mathrm{nd}$ \\
\hline
\end{tabular}

of the sedimentary $\mathrm{NO}_{3}{ }^{-}$content at the Thioploca mat stations, because the pattern of $\mathrm{NO}_{3}{ }^{-}$elution during squeezing suggested that more $\mathrm{NO}_{3}{ }^{-}$remained in the core (Fig. 4). In retrospect, this finding likely resulted from our tendency to select areas with the strongest mat development when subsampling the relatively small area of sediment required for whole-core squeezing.

Analyses of sheathed Thioploca confirmed their high $\mathrm{NO}_{3}$ - content and also showed a high content of S (Table 3). After subtraction of $\mathrm{NO}_{3}{ }^{-}-\mathrm{N}$, the $\mathrm{C}_{\text {org }}: \mathrm{N}$ ratio was close to the Redfield ratio of $6.6: 1$ (Redfield et al. 1963). Most dramatically, the $\mathrm{S}$ content, after subtraction of $\mathrm{SO}_{4}{ }^{2-}$ from sea salt, was $\sim 50 \%$ of $\mathrm{C}_{\text {org }}$ by mass. This high $\mathrm{S}$ content may be attributed to $\mathrm{S}^{0}$ granules contained in the Thioploca filaments (Gallardo 1977; Maier and Gallardo 1984a).

$\mathrm{Mn}$ and $\mathrm{Fe}$-The presence of reactive $\mathrm{Mn}$ oxides was only indicated as an enrichment of extractable $\mathrm{Mn}$ at the sediment surface (c.g. Aller 1980, 1994; Canfield et al. 1993b) at station C41 (Fig. 6), whereas concentrations of

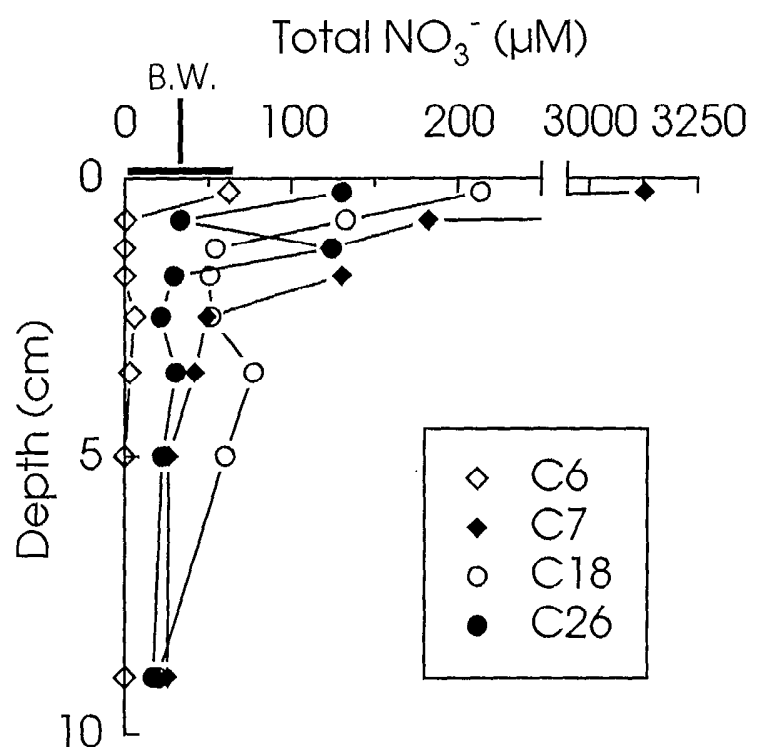

Fig. 5. Depth distributions of initial extractable $\mathrm{NO}_{3}{ }^{-}$in sediments used for incubations. The extracted amounts have been converted to equivalent porc-water concentrations. The bar marked $\mathrm{B}$. W. indicates the range of bottom-water $\mathrm{NO}_{3}{ }^{-}$ concentrations at the shelf stations. 
Table 3. Composition of Thioploca sample.

\begin{tabular}{ccc}
\hline & $\begin{array}{c}\text { Content } \\
(\% \text { dry wt })\end{array}$ & $\begin{array}{c}\mathrm{C}_{\text {org }}: \mathrm{X} \\
(\mathrm{mol}: \mathrm{mol})\end{array}$ \\
\hline $\mathrm{C}_{\text {org }}$ & 12.5 & 1.0 \\
$\mathrm{~N}_{\text {total }}$ & 2.53 & 5.8 \\
$\mathrm{NO}_{3}{ }^{-}-\mathrm{N}$ & 0.61 & 24 \\
$\mathrm{Residue}$ & 1.92 & 7.6 \\
$\mathrm{~S}_{\text {total }}$ & 6.62 & 5.1 \\
$\mathrm{SO}_{4}{ }^{2-}-\mathrm{S}$ & 0.84 & 40 \\
Residue & 5.78 & 5.8 \\
Sea salt & 32.2 & \\
\hline
\end{tabular}

Mn were low $\left(<1 \mu \mathrm{mol} \mathrm{g}^{-1}\right)$ and stable with depth at all other stations (data not shown). The minimal importance of $\mathrm{Mn}$ oxides as electron acceptor was further indicated by only small enrichments of pore-water $\mathrm{Mn}^{2+}$ to $<2 \mu \mathrm{M}$ in the surface sediment, except at $\mathrm{C} 41$, where a maximum of $9 \mu \mathrm{M}$ was reached at $0.5-1-\mathrm{cm}$ depth (Fig. 6).

The contribution to the oxalate-extractable Fe fraction from $\mathrm{Fe}$ (III) decreased with depth and with a concomitant increase in $\mathrm{Fe}(\mathrm{II})$, thus demonstrating Fe reduction, except at $\mathrm{C} 6$, where the $\mathrm{Fe}(\mathrm{III})$ fraction increased slightly with depth (Fig. 7). At the deep stations, all oxalate-extractable $\mathrm{Fe}$ was found as $\mathrm{Fe}(\mathrm{II})$ at depth, whereas stable positive $\mathrm{Fe}(\mathrm{III})$ concentrations were approached at the shallower sites. Because the $\mathrm{Fe}$ (III) at $\mathrm{C} 6$ was measured in the presence of free $\mathrm{H}_{2} \mathrm{~S}$ (Fig. 3), it was clearly of low reactivity, which seemed to be the case for the low "background" Fe(III) concentrations reached at the other shelf stations as well. This result was confirmed by analysis of sediment at the end of the prolonged incubations at $\mathrm{C} 7$ and $\mathrm{C} 18$. Although $\mathrm{H}_{2} \mathrm{~S}$ accumulated to millimolar levels during these incubations (see below), the Fe(III) concentrations did not change in the deeper intervals. At the surface, the $\mathrm{Fe}$ (III) fraction decreased to near the background value (data not shown). When we take the Fe(III) levels reached at depth in the shelf sediments as an unreactive background, poorly crystalline Fe(III) was available for Fe reduction near the surface at all stations except C6, and the penetration depth of Fe(III) increased offshore, reaching 4-5 $\mathrm{cm}$ at $\mathrm{C} 41$. The pool sizes of the poorly crystalline $\mathrm{Fe}(\mathrm{III})$ and reactive $\mathrm{Mn}$ were calculated by subtraction of the unreactive background, taken as the mean concentration at $6-10-\mathrm{cm}$ depth (Table 4).

We did not find an unreactive Fe(III) background at $\mathrm{C} 40$ and $\mathrm{C} 41$, which implies a better selectivity of the oxalate extraction toward poorly crystalline $\mathrm{Fe}$ phases at these stations. This result was likely due to interference from residual $\mathrm{Fe}$ (II) in the shelf sediments. For the determination of oxalate-cxtractable $\mathrm{Fc}$, the sediments were oxidized by air-drying to remove interferences from $\mathrm{Fe}(\mathrm{II})$ (see methods). This process decreased the Fe yield significantly relative to the extraction of Fe from fresh sediment (data not shown), but we speculate that some Fe(II) remained in the very FeS-rich shelf sediments and catalyzed dissolution of crystalline Fe oxides.

The dithionite (DCA) extraction typically yielded 1.5-

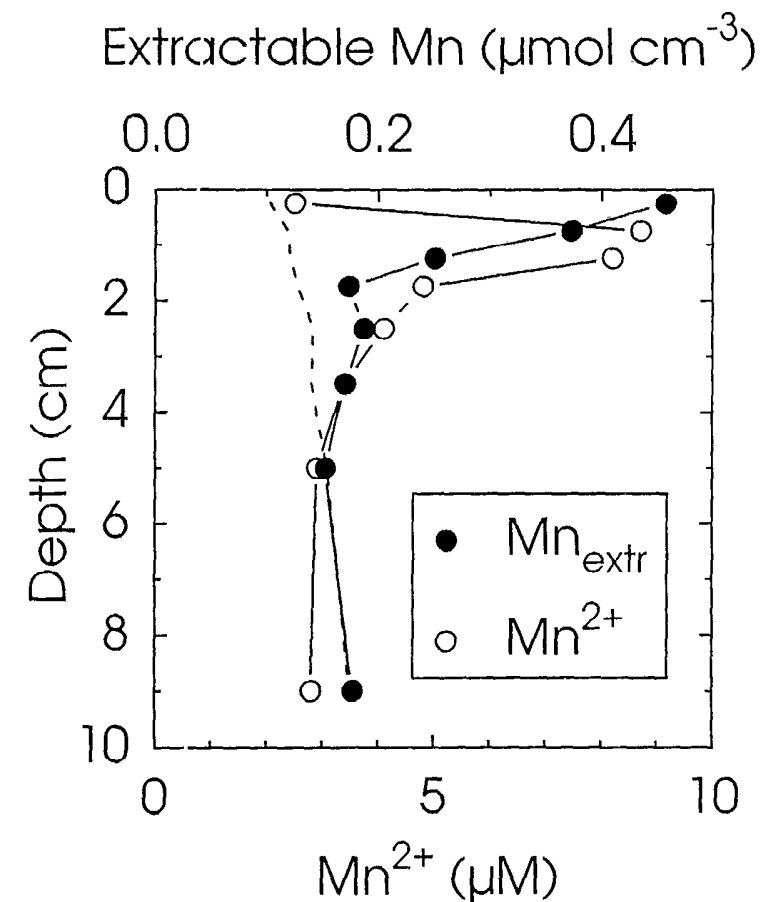

Fig. 6. Depth distributions of extractable and dissolved $\mathrm{Mn}^{2+}$ at station $\mathrm{C} 41$. Note separate axcs. The stippled line shows the unreactive extractable $\mathrm{Mn}$ fraction determined from the decpest sections. This fraction decreases toward the surface owing to increasing porosity.

2 times as much Fe as did the oxalate extraction, and the excess Fe extracted by DCA only showed small changes with depth (data not shown). This result indicated that a large pool of crystalline $\mathrm{Fe}$ oxides of low reactivity was present in all the profiles studicd.

Subsurface rnaxima of dissolved $\mathrm{Fe}^{2+}$ from $\mathrm{Fe}$ reduction were in close accordance with the distribution of poorly crystall:ne Fe(III) (Fig. 3). Thus, C6, which lacked such $\mathrm{Fe}(\mathrm{III})$, had only a small $\mathrm{Fe}^{2+}$ peak at the surface, whereas stations C7-C26 exhibited sharp $\mathrm{Fe}^{2+}$ gradients to $\sim 2-\mathrm{cm}$ depth. At $\mathrm{C} 41$, which had the deepest poorly crystalline $\mathrm{Fe}(\mathrm{III})$ pool, $\mathrm{Fc}^{2+}$ first accumulated at $1-\mathrm{cm}$ depth and reached its maximum at $5-\mathrm{cm}$ depth. The amount of dissolved $\mathrm{Fe}^{2+}$, however, was insignificant in comparison with the $\mathrm{Fe}(\mathrm{II})$ pool extracted in oxalate (Fig. 7). This procedure dissolves $\mathrm{FeS}$ but not $\mathrm{FeS}_{2}$, and at the shallowest stations FeS made up a large fraction of this Fe(II) pool (cf. Figs. 7 and 8). At the other sites, however, most of this Fe(II) was not S-bound, and on the slope, non-S-bound $\mathrm{Fe}(\mathrm{II})$ was the largest $\mathrm{Fe}(\mathrm{II})$ pool measured, exceeding $\mathrm{FeS}_{2}$ by 5 -fold. A large authigenic non-S-bound $\mathrm{Fe}(\mathrm{II})$ pool has been measurcd in other coastal sediments,

Table 4. Pools of reactive Mn and poorly crystalline Fe(III) $\left(\mathrm{mmol} \mathrm{m} \mathrm{m}^{-2}\right)$ (nd-not detected).

\begin{tabular}{llccccc}
\hline & $\mathrm{C6}$ & $\mathrm{C} 7$ & $\mathrm{C} 18$ & $\mathrm{C} 26$ & $\mathrm{C} 40$ & $\mathrm{C} 41$ \\
\hline $\mathrm{Mn}$ & nd & nd & nd & nd & nd & 4.7 \\
$\mathrm{Fe}($ III) & nd & 152 & 131 & 67 & 390 & 769 \\
\hline
\end{tabular}




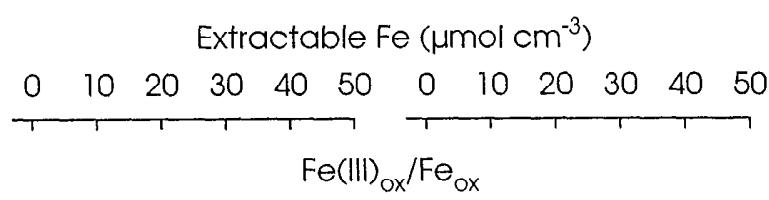

$\begin{array}{llllllllllll}0.0 & 0.2 & 0.4 & 0.6 & 0.8 & 1.0 & 0.0 & 0.2 & 0.4 & 0.6 & 0.8 & 1.0\end{array}$
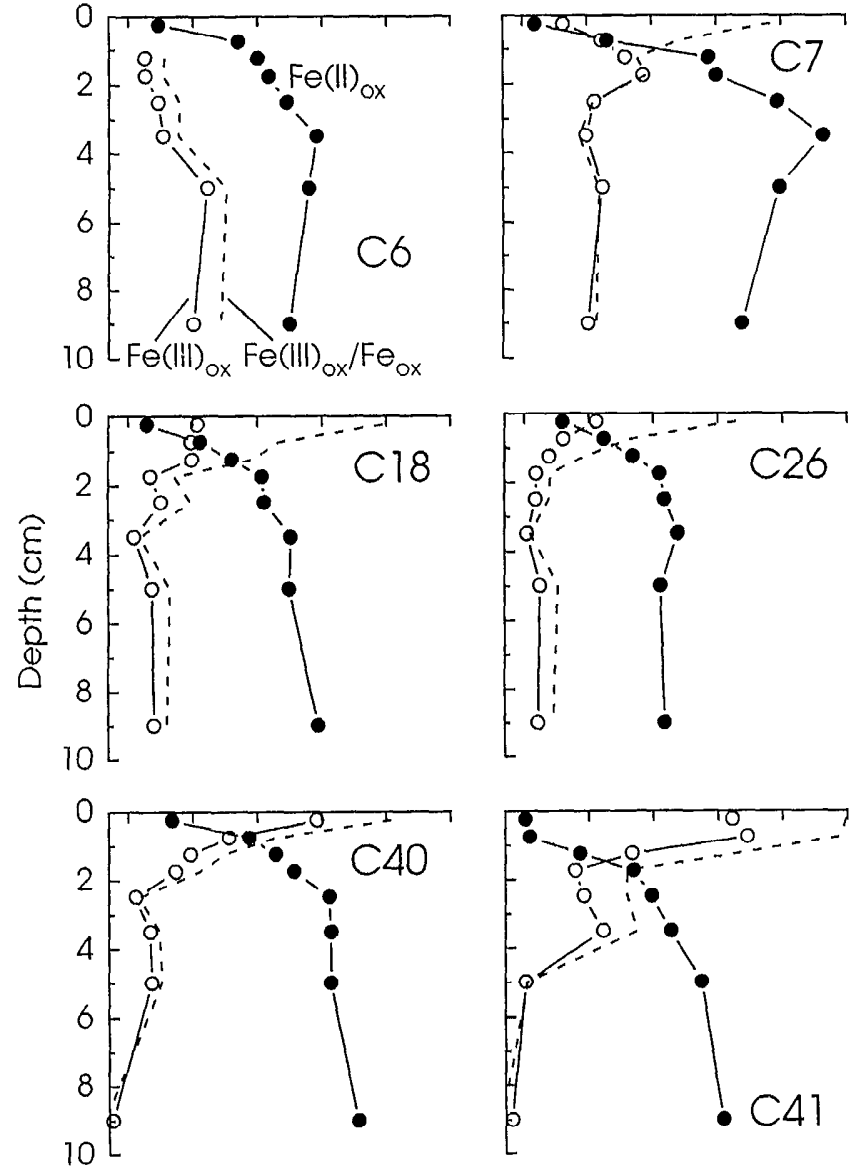

Fig. 7. Depth distributions of oxalate-extractable $\mathrm{Fe}(\mathrm{II})(\mathbf{0})$ and $\mathrm{Fe}(\mathrm{III})(\mathrm{O})$, and the ratio of oxalate-extractable $\mathrm{Fe}$ (III) to total oxalate-extractable Fe (-- ). Note separate scales. Slightly negative concentrations that occurs as $\mathrm{Fe}(\mathrm{III})_{\mathrm{ox}}$ are found by subtraction of two large numbers.

but it is not clear which phases this pool represents (Canfield et al. 1993b; Thamdrup et al. 1994a).

Sulfur-The pore-water concentration of $\mathrm{SO}_{4}{ }^{2-}$ showed no gradient to $10-\mathrm{cm}$ depth at the slope stations or at C26. At $\mathrm{C} 6, \mathrm{SO}_{4}{ }^{2-}$ decreased from the seawater level of $28 \mathrm{mM}$ at the surface to $24 \mathrm{mM}$ at $10-\mathrm{cm}$ depth, whereas at $\mathrm{C} 7$ and $\mathrm{C} 18$ smaller decreases of $\sim 1 \mathrm{mM}$ were observed over this interval (data not shown). High concentrations of $\mathrm{H}_{2} \mathrm{~S}$ were seen only at $\mathrm{C} 6$ (Fig. 3). One core from $\mathrm{C} 18$ showed a small $\mathrm{H}_{2} \mathrm{~S}$ peak of $6 \mu \mathrm{M}$ near the surface, while the concentrations in another core and in the initial samples from the bag incubations (see below) were $\leq 1 \mu \mathrm{M}$. At the other stations, $\mathrm{H}_{2} \mathrm{~S}$ was not detected $(<1 \mu \mathrm{M})$. Solid-phase reduced $\mathbf{S}$ accumulated at all stations, with pyrite $\left(\mathrm{FeS}_{2}\right)$ as the dominating form. Procecding from

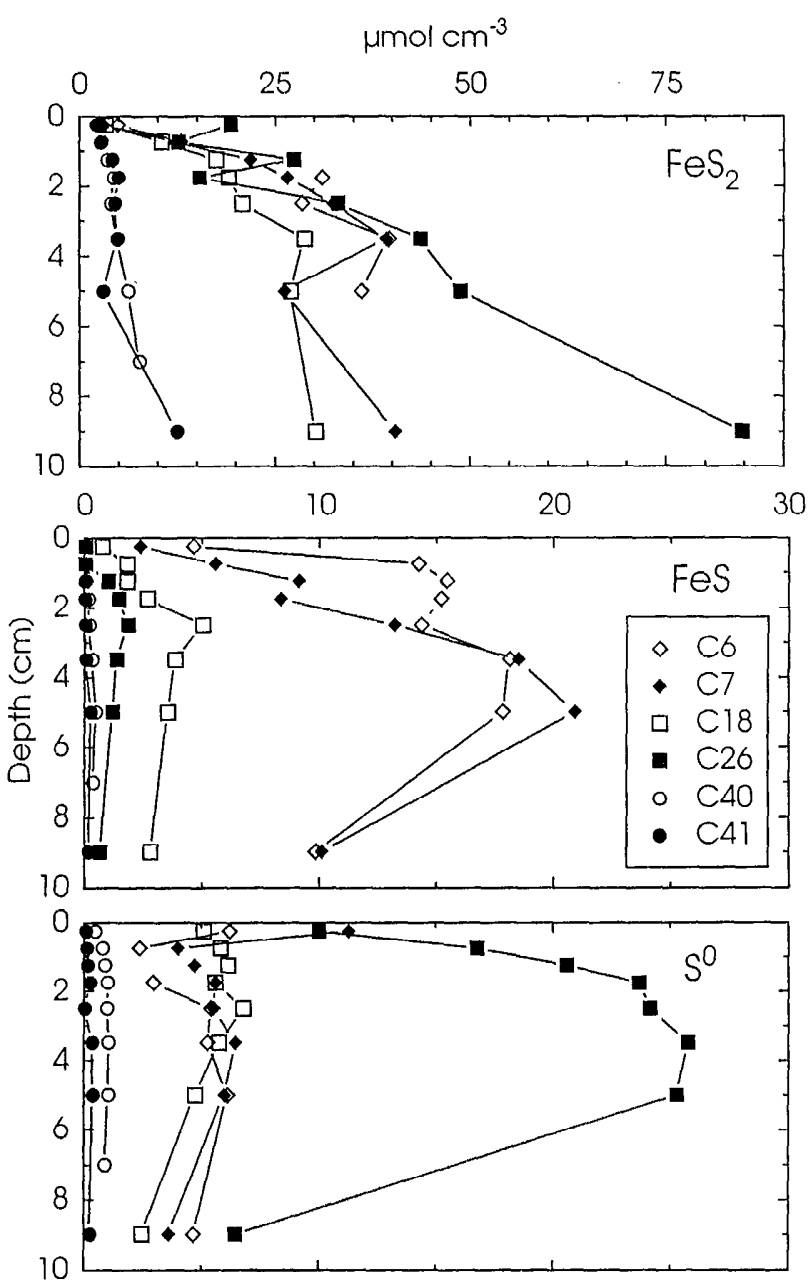

Fig. 8. Depth distributions of reduced sulfur compounds. Note separate scales for $\mathrm{FeS}_{2}$ and $\mathrm{FeS}$ and $\mathrm{S}^{\circ}$.

the inner shelf to the slope stations, the concentrations of all solid-phase S species decreased markedly. Particularly high levels of $\mathrm{FeS}$ were found from the surface at $\mathrm{C} 6$ and $\mathrm{C} 7$, while a subsurface peak of $\mathrm{S}^{0}$ was observed at $\mathrm{C} 26$.

Incubation experiments: Rates of mineralizationHerein we present results from our bag incubations, including total rates of $\mathrm{C}$ mineralization and the contributions of the individual $\mathrm{e}^{-}$acceptors to this process. The increases in concentrations of both $\Sigma \mathrm{CO}_{2}$ and $\mathrm{NH}_{4}{ }^{+}$measured during the short-term sediment incubations were generally linear and showed no systematic deviation from linearity at any station (C7 and C41 shown in Fig. 9). Extended incubations of sediment from $\mathrm{C} 7$ and $\mathrm{C} 18$ showed that $\Sigma \mathrm{CO}_{2}$ and $\mathrm{NH}_{4}{ }^{+}$accumulation rates were stable over a period several times longer than that used for the rate determinations (Fig. 10). Only the surface section from $\mathrm{Cl} 8$ showed a gradual decrease in $\mathrm{\Sigma CO}_{2}$ accumulation rates during the $10-\mathrm{d}$ incubation.

Both maximum and depth-integrated rates of $\Sigma \mathrm{CO}_{2}$ and $\mathrm{NH}_{4}{ }^{+}$accumulation werc extremely high at the shelf 

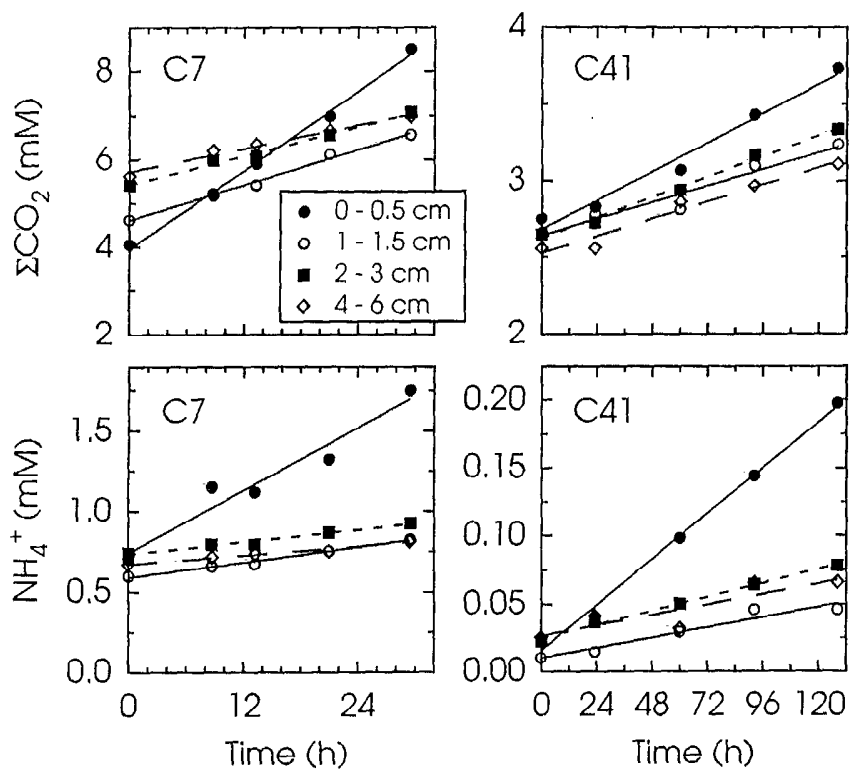

Fig. 9. Examples of $\mathrm{\Sigma CO}_{2}$ and $\mathrm{NH}_{4}{ }^{+}$concentration changes during the short-term incubations of sediment from the sites with the highest (C7) and lowest (C41) activities. Note different time and concentration scales.

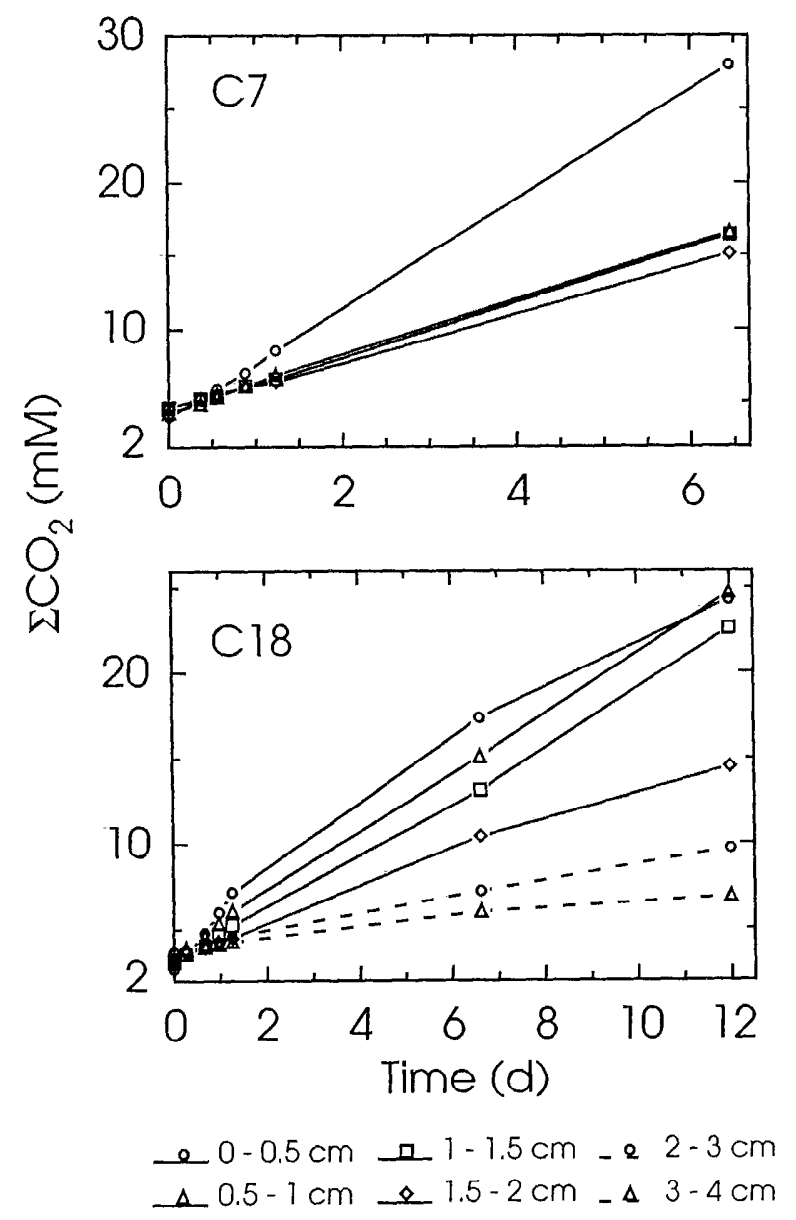

Fig. 10. Changes in $\mathrm{2CO}_{2}$ concentrations during the prolonged incubations of sediment from $\mathrm{C} 7$ and $\mathrm{C} 18$.
Table 5. Depih-integrated accumulation and $\mathrm{SO}_{4}{ }^{2-}$ reduction rates $\left(\mathrm{mmol} \mathrm{m}^{-2} \mathrm{~d}^{-1}\right)$ at $0-10-\mathrm{cm}$ depth $(0-8 \mathrm{~cm}$ at $\mathrm{C} 40)$.

\begin{tabular}{cccc}
\hline \hline & \multicolumn{2}{c}{ Accumulation* } & $\begin{array}{c}\mathrm{SO}_{4}{ }^{2-} \\
\text { reduction } \dagger\end{array}$ \\
\cline { 2 - 3 } & $\mathrm{xO}_{2}$ & $\mathrm{NH}_{4}{ }^{+}$ & 42.5 \\
$\mathrm{C} 6$ & 95.7 & 9.4 & 55.9 \\
$\mathrm{C} 7$ & $107 \pm 3$ & $14.1 \pm 0.8$ & $32.8 \pm 3.7$ \\
$\mathrm{C} 18$ & $56.3 \pm 1.3$ & $7.8 \pm 0.5$ & $29.9 \pm 6.0$ \\
$\mathrm{C} 26$ & $50.3 \pm 1.9$ & $6.8 \pm 0.3$ & $4.80 \pm 0.69$ \\
$\mathrm{C} 40$ & $11.15 \pm 0.6$ & $1.11 \pm 0.04$ & $2.66 \pm 0.46$ \\
$\mathrm{C} 41$ & $9.2 \pm 0.4$ & $0.81 \pm 0.07$ & \\
\hline
\end{tabular}

* \pm SE from linear regression.

$\uparrow$ Mean \pm half the span from depth-integration of maxima and minima of duplicates. Single detcrminations at C6 and C7.

stations and decreased 10-fold offshorc (Fig. 11, Table 5). There was a close covariation between $\mathrm{\Sigma CO}_{2}$ and $\mathrm{NH}_{4}{ }^{+}$ accumulation rates at all sites. The ratio of $\mathrm{\Sigma CO}_{2}$ accumulation to $\mathrm{NH}_{4}{ }^{+}$accumulation showed no systematic depth variation, but mean values increased from $\sim 8$ on the shelf to 11-12 on the slope (Table 6). Ammonium adsorbs to sediment particles (Rosenfeld 1979), and the rate of $\mathrm{NH}_{4}{ }^{+}$acc Imulation in the pore water consequently underestimates the rate of $\mathrm{NH}_{4}{ }^{+}$production from organic decomposition. The rate of $\mathrm{NH}_{4}{ }^{+}$production can be estimated from the relation (Berner 1980)

$$
\begin{aligned}
& \text { Rate }\left(\mathrm{NH}_{4}{ }^{+} \text {production }\right)= \\
& \quad \text { Rate }\left(\mathrm{NH}_{4}{ }^{+} \text {accumulation }\right) \times(1+K),
\end{aligned}
$$

where $K$ is the dimensionless adsorption coefficient with a typical value of $1.3 \pm 0.1$ in coastal sediments (Mackin and Aller 1984). When this value is used, the average ratios of $\Sigma \mathrm{CO}_{2}$ tc. $\mathrm{NH}_{4}{ }^{+}$accumulation in Table 6 correspond to $\Sigma \mathrm{CO}_{2}$ to $\mathrm{NH}_{4}{ }^{+}$production ratios of $3.4(\mathrm{Cl} 18)$ to $5.2(\mathrm{C} 41)$, provided that $\Sigma \mathrm{CO}_{2}$ accumulation was unaffected by the dissolution or precipitation of carbonates.

Calcium carbonate is probably the most significant factor to consider with respect to interference from carbonate dissolution or precipitation. Also, significant precipitation of the relatively minor carbonate francolite (carbonate fluoroapatite; Froelich et al. 1988) was excluded through measurernents of dissolved $\mathrm{F}^{-}$during the incubations. To constrain $\mathrm{CaCO}_{3}$ dissolution or precipitation,

Table 6. $\Sigma \mathrm{CO}_{2}: \mathrm{NH}_{4}{ }^{+}$accumulation ratios in sediment incubations ( $\mathrm{mol}: \mathrm{mol})$.

\begin{tabular}{llrrrr}
\hline \hline Depth $(\mathrm{cm})$ & C7 & C18 & C26 & C40 & C41 \\
\hline $0-0.5$ & 4.6 & 7.1 & 16.0 & 8.5 & 5.7 \\
$0.5-1$ & 6.9 & 5.8 & 11.5 & 10.6 & 8.9 \\
$1-1.5$ & 8.7 & 7.1 & 7.8 & 15.9 & 14.4 \\
$1.5-2$ & 9.1 & 7.3 & 8.4 & 16.9 & 8.0 \\
$2-3$ & 8.8 & 8.6 & 4.9 & 14.1 & 13.2 \\
$3-4$ & 7.7 & 4.6 & 7.2 & 6.7 & 11.4 \\
$4-6$ & 9.8 & 13.2 & 6.6 & 13.2 & 14.7 \\
$8-10^{*}$ & 9.1 & 9.6 & 7.3 & 10.5 & 13.1 \\
Mean & 8.1 & 7.9 & 8.7 & 12.1 & 11.2 \\
\hline
\end{tabular}

* At C40, 6-8-cm depth. 


\section{Accumulation rates ( $\mathrm{nmol} \mathrm{cm}^{-3} \mathrm{~d}^{-1}$ )}

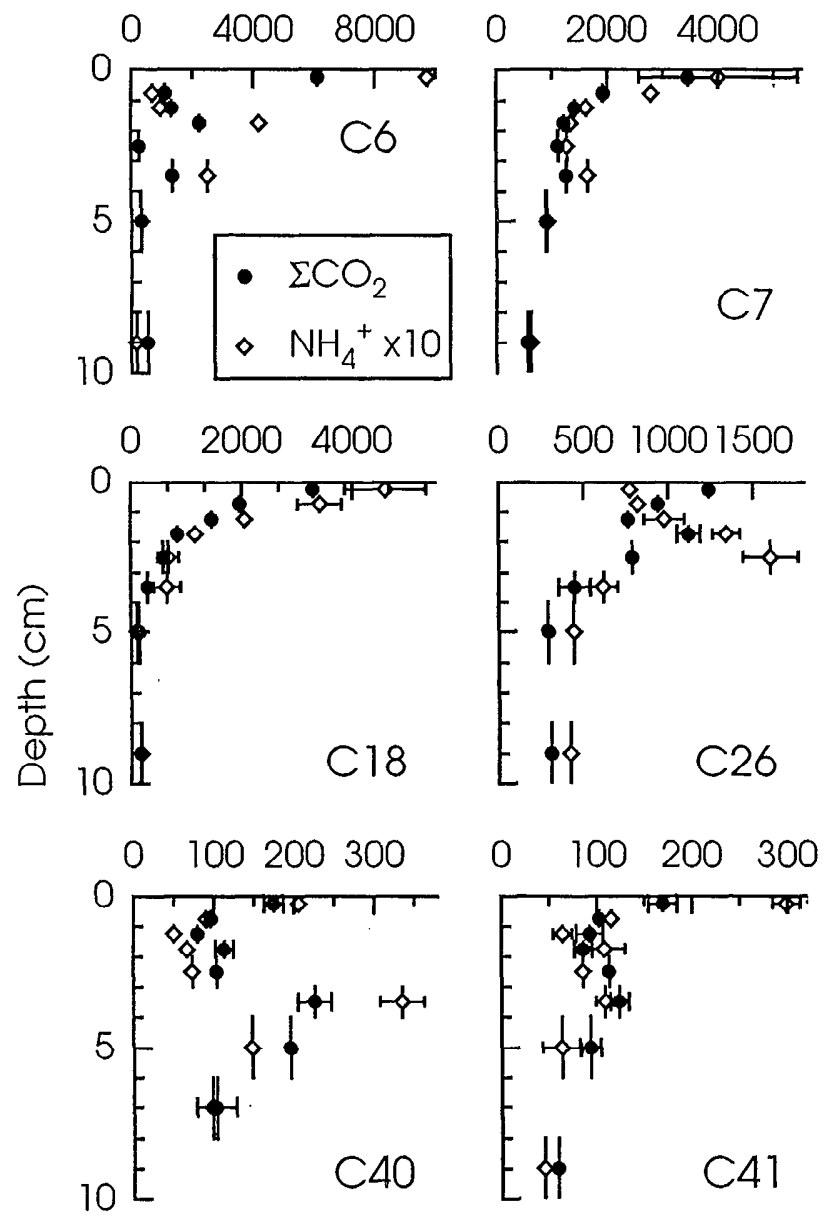

Fig. 11. Depth distributions of $2 \mathrm{CO}_{2}$ and $\mathrm{NH}_{4}{ }^{+}$accumulation rates $\pm \mathrm{SE}$ at all stations. Note that rates for $\mathrm{NH}_{4}^{+}$have been multiplied by 10 . Errors could not be calculated for $\mathrm{C} 6$.

ion molality products (IMP) were first calculated from $\mathrm{Ca}^{2+}$ and $\mathrm{\Sigma CO}_{2}$ concentrations and $\mathrm{pH}$ and then compared to the apparent solubility constant, $K_{s p}{ }^{\prime}$, of calcite (Mucci 1983), which in the form of foraminiferal tests was found to be the main contributor to the low carbonate content of the sediments (Fig. 12). Carbonic acid dissociation constants in seawater at $34.5 \% \mathrm{~S}$ and $11.5^{\circ} \mathrm{C}$ (shelf sites) or $5^{\circ} \mathrm{C}$ (slope sites) were used (Mehrbach et al. 1973). Concentrations of pore-water $\mathrm{Ca}^{2+}$ did not deviate significantly from the bottom-water level (data not shown). Pore waters at $\mathrm{C} 7$ were supersaturated with respect to calcite, whereas clear undersaturation was observed at $\mathrm{C} 18$ and $\mathrm{C} 26$ and near the surface at C40 and C41. Measurements of dissolved $\mathrm{Ca}^{2+}$, however, indicated no change during any of the incubations to levels exceeding the precision of the $\mathrm{Ca}^{2+}$ determination (data not shown). Given this precision, $\Sigma \mathrm{SO}_{2}$ changes owing to $\mathrm{CaCO}_{3}$ precipitation or dissolution were limited to $<70$ and $<30$ $\mathrm{nmol} \mathrm{cm} \mathrm{cm}^{-3} \mathrm{~d}^{-1}$ during the prolonged incubations at $\mathrm{C} 7$ and $\mathrm{C} 18$. Because $\Sigma \mathrm{CO}_{2}$ accumulation rates at $\mathrm{C} 7$ and C18 (Fig. 11) were much higher than these values, we

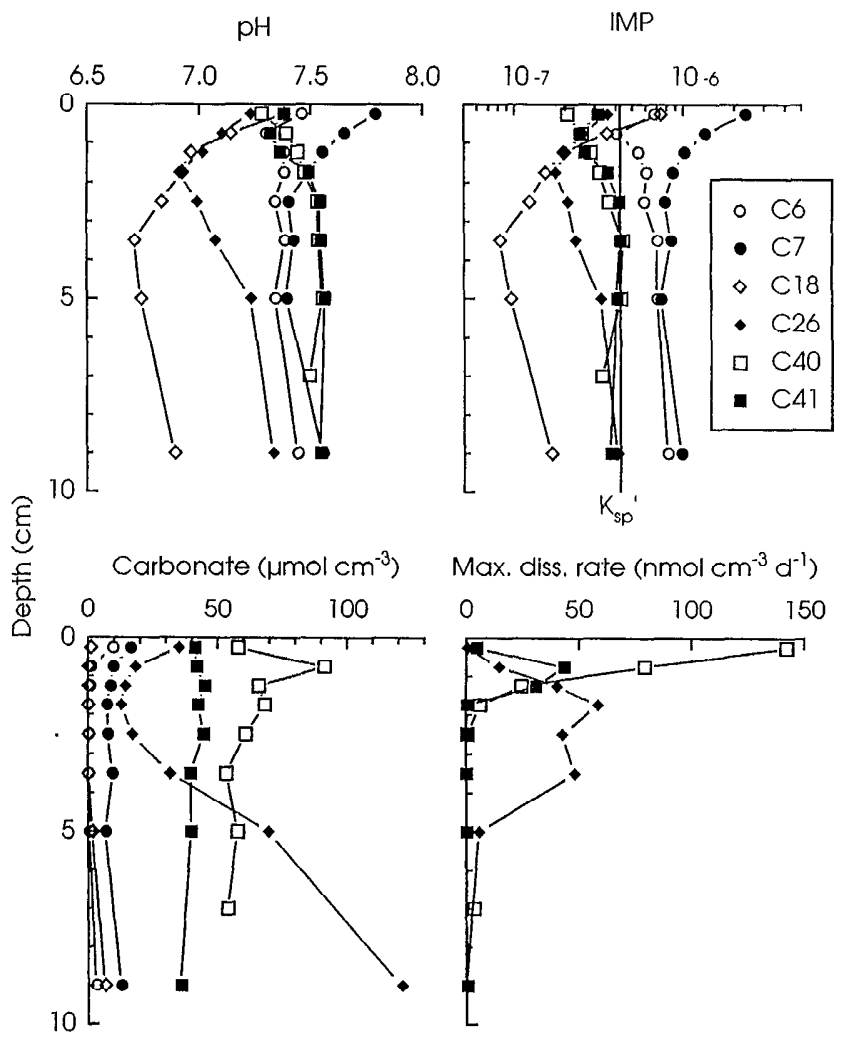

Fig. 12. Depth distributions of parameters used in carbonate dissolution rate calculations. $\mathrm{pH}$ was measured at the end of the short-term incubations. For ion molality products (IMP, see text), the vertical line represents the apparent solubility constant of calcite. Dissolution rates were calculated assuming $k$ of $5 \%$ $\mathrm{d}^{-1}$ (Eq. 1).

immediately excluded a significant contribution from $\mathrm{CaCO}_{3}$ precipitation or dissolution to the $\mathrm{C}$ accumulation rates for these stations. At the remaining stations, the shorter incubation times made the potential precipitation or dissolution rates correspondingly larger (i.e. 250,110 , and $80 \mathrm{nmol} \mathrm{cm}^{-3} \mathrm{~d}^{-1}$ at $\mathrm{C} 26, \mathrm{C} 40$, and $\mathrm{C} 41$, respectively).

To further constrain calcite dissolution rates at the outer stations that experienced undersaturation, we applied a normal rate law expression with dissolution rate as a function of $\mathrm{CaCO}_{3}$ content and degree of undersaturation:

$$
\frac{\mathrm{dCa}^{2+}}{\mathrm{d} t}=\mathrm{C}_{\mathrm{CaCO}_{3}} \times k \times\left(1-\frac{\mathrm{IMP}}{K_{s p}^{\prime}}\right)^{n} .
$$

$k$ is a rate constant, $\mathrm{C}_{\mathrm{CaCO}_{3}}$ is the carbonate content, and $n$ equals 4.5 for calcite (Morse 1978; Keir 1980). For the undersaturated surface intervals at $\mathrm{C} 40$ and $\mathrm{C} 41$, dissolution rates similar to the mcasured $\Sigma \mathrm{CO}_{2}$ accumulation rates (Fig. 11) may be generated by using $k$ of $5 \% \mathrm{~d}^{-1}$ (Fig. 12). At this value of $k, \mathrm{CaCO}_{3}$ dissolution could only contribute to the measured $\mathrm{\Sigma CO}_{2}$ accumulation above $1.5-\mathrm{cm}$ depth. However, significant $\mathrm{CaCO}_{3}$ dissolution in the surface sediments should increase the accumulation ratios of $\Sigma \mathrm{CO}_{2}$ to $\mathrm{NH}_{4}{ }^{+}$to higher values than in the deeper 
$\mathrm{SO}_{4}{ }^{2-}$ reduction rates $\left(\mathrm{nmol} \mathrm{cm} \mathrm{cm}^{-3}\right)$

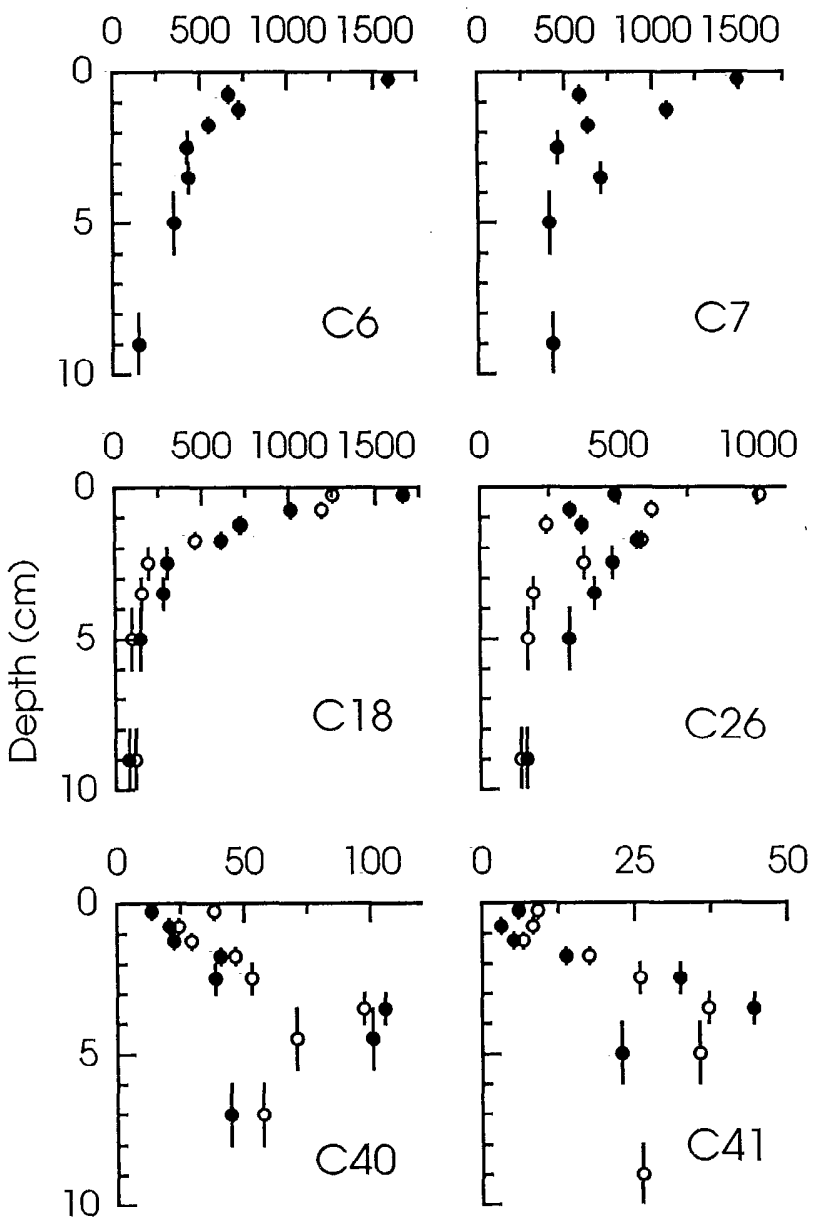

Fig. 13. Depth distributions of $\mathrm{SO}_{4}{ }^{2-}$ reduction rates from all stations $(-$ first determination; $\mathrm{O}-$ second determination; only one determination was made at $\mathrm{C} 6$ and $\mathrm{C7}$ ).

layers, where dissolution cannot occur. By contrast, the observed $\Sigma \mathrm{\Sigma O}_{2}: \mathrm{NH}_{4}{ }^{+}$ratios increase with depth (Table 6 ). The same is the case at $\mathrm{C} 26$, where the potential dissolution rates increase from the surface while $\Sigma \mathrm{CO}_{2}: \mathrm{NH}_{4}{ }^{+}$ accumulation ratios decrease. Also, a comparison between stations does not support significant $\mathrm{CaCO}_{3}$ dissolution rates, because $\Sigma \mathrm{CO}_{2}: \mathrm{NH}_{4}{ }^{+}$accumulation ratios in zones where dissolution could be significant are comparable to zones where dissolution has been excluded. From these considerations, we conclude that the $\Sigma \mathrm{CO}_{2}$

Table 7. Molar ratio of $\Sigma \mathrm{CO}_{2}$ production to $\mathrm{SO}_{4}{ }^{2-}$ consumption during prolonged incubations.

\begin{tabular}{lcc}
\hline Depth $(\mathrm{cm})$ & $\mathrm{C} 7$ & $\mathrm{C} 18$ \\
\hline $0-0.5$ & 2.21 & 1.98 \\
$0.5-1$ & 1.89 & 1.93 \\
$1-1.5$ & 1.59 & 1.93 \\
$1.5-2$ & 2.42 & 1.67 \\
Mean \pm SD: & \multicolumn{2}{c}{$1.95 \pm 0.26$} \\
\hline
\end{tabular}
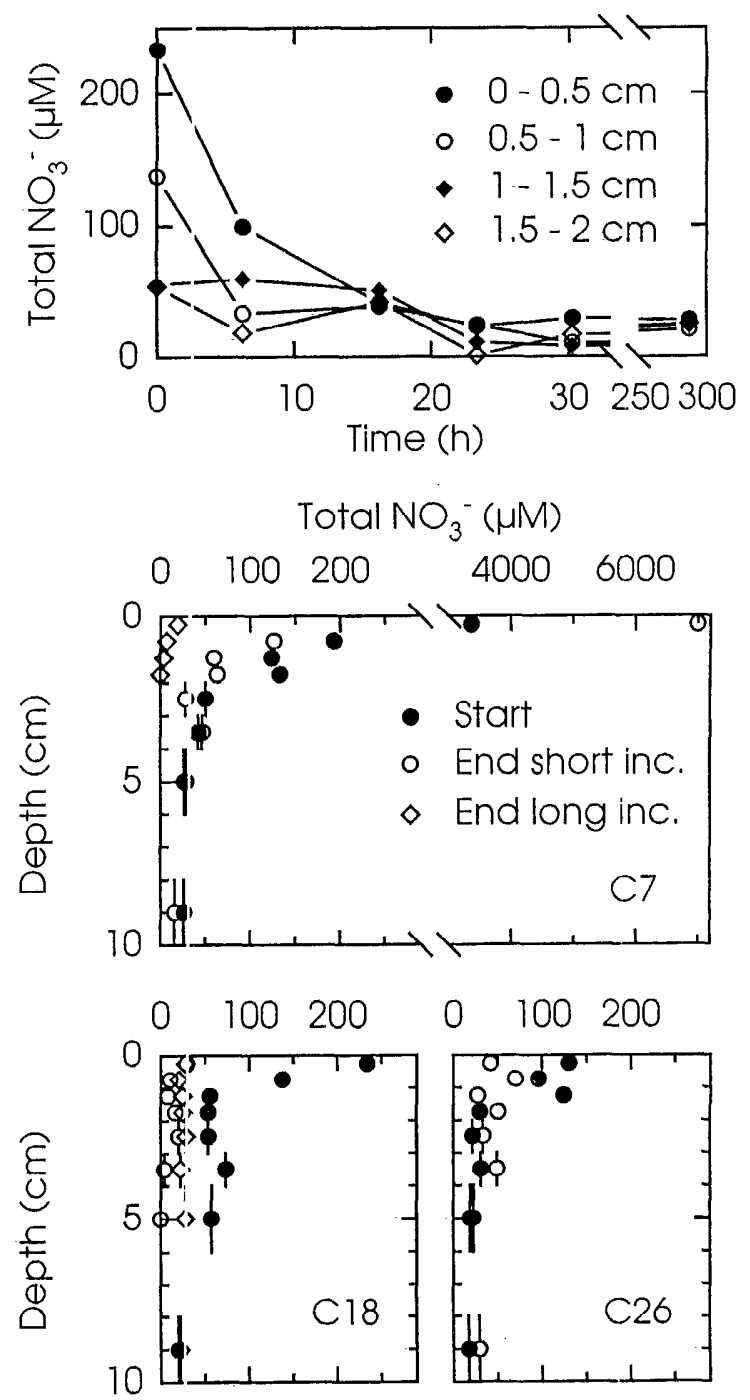

Fig. 14. Changes in extractable $\mathrm{NO}_{3}{ }^{-}$concentrations during sediment incubations. Top: Time course from short-term $(0-$ $30 \mathrm{~h}$ ) and prolonized (to $300 \mathrm{~h}$ ) incubations of four depth intcrvals at C18. Center and bottom: Depth distributions at the beginning and erd of the short-term incubations as well as at the end of the prolonged incubations ( $\mathrm{C} 7,0-2 \mathrm{~cm}$ and $\mathrm{C} 18$ only).

accumulation rates represent $\mathrm{C}$ oxidation and may be only marginally affected by dissolution or precipitation.

Sulfate reduction-Rates of $\mathrm{SO}_{4}{ }^{2-}$ reduction measured by means of the radio tracer technique resembled rates of $\mathrm{C}$ mineralization (i.e. extreme surface rates and exponential decreases with depth on the shelf, as well as lower rates downslope; Fig. 13). In contrast to the $\mathrm{C} \mathrm{min-}$ eralization rates, however, surface rates of $\mathrm{SO}_{4}{ }^{2-}$ reduction at $\mathrm{C} 40$ and $\mathrm{C} 41$ were low, with pronounced subsurface maxima at $3-4 \mathrm{~cm}$. At the slope sites and at $\mathrm{C} 18$, little variability was observed between the two $\mathrm{SO}_{4}{ }^{2-}$ reduction rate determinations, whereas larger but unsystematic variation was observed at $\mathrm{C} 26$ (Table 5, Fig. 13).

The mean ratio of $\Sigma \mathrm{CO}_{2}$ production to $\mathrm{SO}_{4}{ }^{2-}$, depletion 
Table 8. Mean $\mathrm{NO}_{3}{ }^{-}$consumption rates $\left(\mathrm{nmol} \mathrm{cm}{ }^{-3} \mathrm{~d}^{-1}\right)$ during bag incubations (nd-not detected).

\begin{tabular}{lccl}
\hline \multicolumn{1}{c}{ Depth $(\mathrm{cm})$} & C7 & C18 & C26 \\
\hline $0-0.5$ & $450^{*}$ & 158 & 55 \\
$0.5-1$ & 38 & 85 & 19 \\
$1-1.5$ & 45 & 22 & 58 \\
$1.5-2$ & 47 & 20 & 13 \\
$2-3$ & 15 & 18 & nd \\
$3-4$ & nd & 36 & nd \\
$4-6$ & nd & 21 & nd \\
$8-10$ & nd & nd & nd \\
$\Sigma, \mathrm{mmol} \mathrm{m}^{-2} \mathrm{~d}^{-1}$ & 3.1 & 2.6 & 0.7 \\
\hline
\end{tabular}

* Mean rate over entire incubation (see text).

during the prolonged incubations was close to 2.0 (Table 7). The uppermost interval at $\mathrm{C} 7$ was an exception, as a large $\mathrm{NO}_{3}{ }^{-}$pool persisted throughout the short-term incubation and could have contributed to $\mathrm{C}$ oxidation or reoxidation of $\mathrm{H}_{2} \mathrm{~S}$ during the prolonged incubation (see below). This pool may explain the higher $\Delta \Sigma \mathrm{CO}_{2}: \Delta \mathrm{SO}_{4}{ }^{2-}$ ratio observed there. Otherwise, the larger deviations from the mean ratio were found in the incubations with the smallest concentration changes and, hence, the largest associated errors.

During the short-term incubations, $\mathrm{H}_{2} \mathrm{~S}$ was detected only at $\mathrm{C} 6$ and at $8-10-\mathrm{cm}$ depth at $\mathrm{C} 7$, where it rose from below detection to $64 \mu \mathrm{M}$ in $30 \mathrm{~h}$. In the prolonged incubation of $\mathrm{C} 7$ and $\mathrm{C} 18$ sediments, however, $\mathrm{H}_{2} \mathrm{~S}$ accumulated rapidly in the upper sections, with maximum concentrations reaching 4.5 and $3.0 \mathrm{mM}$ at the surface of $\mathrm{C} 7$ and $\mathrm{Cl} 8$, respectively. An even larger increase was observed in acid-volatile sulfide (AVS $=\mathrm{H}_{2} \mathrm{~S}+\mathrm{FeS}$; data not shown), and FeS precipitation was seen as a blackening of the sediments.

Other $C$ oxidation pathways-Although both $\mathrm{O}_{2}$ and $\mathrm{NO}_{3}{ }^{-}$persisted to $5-10 \mathrm{~mm}$ in the pore waters at $\mathrm{C} 40$ and $\mathrm{C} 41$, their presence was dependent on a continuous supply from the bottom water. Because the sediment was sectioned for the incubation experiments, this supply was cut off, and the small standing stocks of the two species were rapidly depleted at the beginning of the incubations (data not shown). At the anoxic shelf sites, total sediment $\mathrm{NO}_{3}$ - contents generally decreased during the incubations (Fig. 14) (the time course from $\mathrm{C} 18$ is given as an example). As discussed above, most of the $\mathrm{NO}_{3}{ }^{-}$was present within the Thioploca, and the stable background level of about $20 \mu \mathrm{M}$ is assumed to be an artifact from the extraction. The overall highest $\mathrm{NO}_{3}{ }^{-}$contents were measured at $0-0.5-\mathrm{cm}$ depth at $\mathrm{C} 7$, and this short-term incubation alone showed an increase in $\mathrm{NO}_{3}{ }^{-}$. Because $\mathrm{NO}_{3}{ }^{-}$production is not likely during the anoxic incubation, we expect this result to be due to the presence of $\mathrm{NO}_{3}{ }^{-}$-rich Thioploca bundle(s) in the subsample taken from the bag after the short-term incubation. At the end of the prolonged incubation, $\mathrm{NO}_{3}{ }^{-}$was depleted to the background level at this depth too.

Average rates of $\mathrm{NO}_{3}{ }^{-}$consumption during the short-

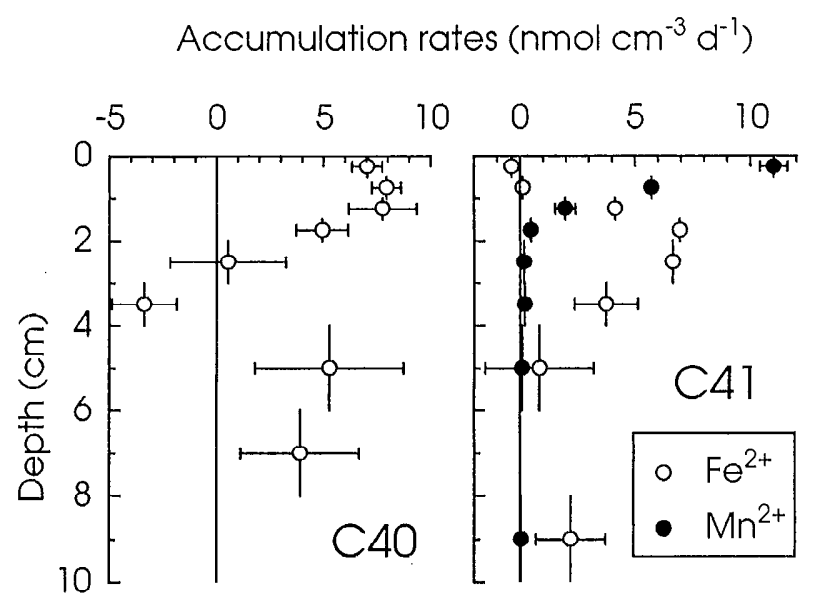

Fig. 15. Depth distributions of accumulation rates $\pm \mathrm{SE}$ of dissolved $\mathrm{Fe}^{2+}$ and $\mathrm{Mn}^{2+}$ during sediment incubations. At $\mathrm{C} 40$, no $\mathrm{Mn}^{2+}$ accumulated.

term incubations are given in Table 8. For 0-0.5-cm depth at $\mathrm{C} 7$, the rate has been estimated by means of the initial concentration and the $\mathrm{NO}_{3}{ }^{-}$depletion observed at the end of the prolonged incubation. The time course of $\mathrm{NO}_{3}{ }^{-}$ consumption for $\mathrm{C} 18$ (Fig. 14) showed that rates were not constant but decreased as the background level was approached. The average rates may therefore underestimate the initial rates and thereby presumably also the in situ $\mathrm{NO}_{3}{ }^{-}$consumption.

Pore-water $\mathrm{Mn}^{2+}$ accumulated steadily at $\mathrm{C} 4 \mathrm{l}$ between 0 and $1-\mathrm{cm}$ depth (Fig. 15), in accordance with the distribution of reactive Mn oxidcs (Fig. 6), whereas the concentration remained $<4 \mu \mathrm{M}$ for all other incubations at all other stations. Also, at C41 significant buildup of dissolved $\mathrm{Fe}^{2+}$ was observed throughout the incubation in the sections from $1-$ to $4-\mathrm{cm}$ depth, and at C40 from 0 to $2 \mathrm{~cm}$ (Fig. 15). Deeper in these sediments, the changes in $\mathrm{Fe}^{2+}$ were too small relative to the high initial concentrations for liberation to be detected with certainty. At all the shelf sites, $\mathrm{Fe}^{2+}$ in the pore water increased only at $0-0.5 \mathrm{~cm}$ (data not shown). In decper sections, the $\mathrm{Fe}^{2+}$ concentration was constant or decreased owing to precipitation of solid $\mathrm{Fe}(\mathrm{II})$.

\section{Discussion}

Rates of $\mathrm{C}$ oxidation-By measuring the accumulation of $\Sigma \mathrm{CO}_{2}$, we have directly quantified the rates and depth distribution of carbon mineralization in the sediments. A significant influence from carbonate dissolution or precipitation could be excluded at all of these metabolically active sites. Würgler bags provided a convenient setup for repeated pore-water sampling and thercby for determination of accurate $\mathrm{C}$ oxidation rates. We kept incubations brief so that the original metabolic pathways and sediment microbial populations were maintained as well as possible. Accumulation rates of $\Sigma \mathrm{CO}_{2}$ and $\mathrm{NH}_{4}{ }^{+}$were therefore stable throughout the short-term incubations (Fig. 9) and were even quite stable when incubations were 
continued much longer (Fig. 10). In situ measurements of $\mathrm{\Sigma CO}_{2}$ fluxes from the shelf sediments (R. N. Glud et al. in prep.) showed a considerable local variability, but the range of flux rates corroborates the range of depthintegrated $\mathrm{C}$ oxidation rates from the bag incubations (Table 5). Further evidence that the sectioning and homogenization of sediment necessary for the incubations did not lcad to major immediate changes in the turnover rates was that both the depth-integrated and the maximal $\mathrm{SO}_{4}{ }^{2-}$ reduction rates agreed well with those obtained with the whole-core injection technique during the same cruise (Jørgensen 1978; T. G. Ferdelman et al. in prep.). Canfield et al. (1993a) found that depth-integrated C oxidation rates in their bag incubations were about twice as high as rates determined from flux measurements, but they suggested that this could result from too high tempcrature during incubation and sediment handling or from decay of entombed fauna. Our results do not indicate a similar strong stimulation of $\mathrm{C}$ mineralization during the incubations, and hence we take the rates as estimates of the in situ sediment metabolism.

The rates of $\mathrm{C}$ oxidation in sediments of the Chilean margin (Fig. 11) ranged from high to extreme. The maxima are an order of magnitude higher than those found in sediments of the Norwegian Trough (Canfield et al. $1993 b$ ) or the Amazon shelf (Aller et al. 1996). The depthintegrated rates from the shelf (Table 5) are the highest reported from open waters (cf. Henrichs 1992; Canfield 1993) and are similar to results from small coastal embayments with very rapid sediment accumulation, such as Cape Lookout Bight, North Carolina (Martens and Klump 1984). Also, the $\mathrm{SO}_{4}{ }^{2-}$ reduction rates from the shelf sites (Table 5) were similar to those in Cape Lookout Bight (Crill and Martens 1987) and the maxima approached those measured in solar pond-microbial mats (Jørgensen and Cohen 1977; Canfield and Des Marais 1991). The extreme activity is further demonstrated by comparison to $\mathrm{SO}_{4}{ }^{2-}$ reduction rates in sediments from the Peru upwelling region, which is also covered with Thioploca. There, Fossing (1990) measured rates of 4-26 mmol m-2 $\mathrm{d}^{-1}$ to $20-\mathrm{cm}$ depth with maxima up to 300 $\mathrm{nmol} \mathrm{cm} \mathrm{cm}^{-3} \mathrm{~d}^{-1}$ (i.e. 5 times lower than those presented here).

Although eutrophic conditions with mass mortality of fauna were observed 100 yr ago in Concepción Bay (Ahumada et al. 1983), stations at the mouth of the Bay (C6 and C7) could presently be affected by further eutrophication from the town of Talcahuano. The continued intense $\mathrm{C}$ oxidation offshore at $\mathrm{C} 18$ and $\mathrm{C} 26$, however, could only be sustained by extreme primary productivity owing to upwelling. High productivity was obvious from both the $\mathrm{O}_{2}$ depletion in the water column and from direct measurements during the cruise that showed total primary productivities over the shelf of $\sim 10 \mathrm{~g} \mathrm{C} \mathrm{m}^{-2} \mathrm{~d}^{-1}$ (O. Ulloa pers. comm.) and the productivity supports an intense (human and avian) fishery in the region.

Variations in $\mathrm{C}$ oxidation rates were only weakly reflected in the $\mathrm{C}_{\text {org }}$ content of the sediments (Figs. 2, 11). The turnover times for $\mathrm{C}_{\text {org }}$ (concn/oxidation rate) in the surface mat at $\mathrm{C} 7$ and $\mathrm{C} 18$ were extremely short, 0.22 and $0.41 \mathrm{yr}$, respectively, which corresponds to rate con- stants of 4.5 and $2.4 \mathrm{yr}^{-1}$, assuming first-order decay of $\mathrm{C}_{\text {org }}$. These constants approach those of fresh plankton (Westrich and Berner 1984), which implies a close coupling of benthic $\mathrm{C}$ oxidation and production in the water column. The thrnover time for $\mathrm{C}_{\text {org }}$ increased dramatically both with sediment depth, reaching 4.9 and $12 \mathrm{yr}$ at 8-10-cm depth at $\mathrm{C} 7$ and $\mathrm{Cl}$, and with water depth, rcaching 13 ancl $57 \mathrm{yr}$ in the top and bottom sections at C41, respectively. The large variation in reactivity was not due to differences in $\mathrm{C}$ oxidation pathways, because $\mathrm{SO}_{4}{ }^{2-}$ reduction was the dominating respiration at all depths at the shelf stations as well as at the deepest section of $\mathrm{C} 41$ (see below). The varying reactivities of $\mathrm{C}_{\text {org }}$ were only weakly reflected in the $\mathrm{C}_{\text {org }}: \mathrm{N}$ ratios (Fig. 2) and in the $\Sigma \mathrm{CO}_{2}: \mathrm{NH}_{4}{ }^{+}$accumulation ratios (Table 6).

Although the reactivity of $\mathrm{C}_{\text {org }}$ decreased offshore, the rates of decomposition at 1,000- and 2,000-m depth were still high and within the range of many shelf sediments (Devol and Christensen 1993; Canfield 1993; Canfield et al. 1993a). The depth dependence of C oxidation rates (COR) was fit closely by the power function

$$
\begin{gathered}
\mathrm{COR}_{\text {total }}=54.4 \mathrm{mmol} \mathrm{m}^{-2} \mathrm{~d}^{-1} \times(z / 100)^{-0.60 \pm 0.07} \\
(R=0.991) .
\end{gathered}
$$

$z$ is water depth in meters. Devol and Christensen (1993) fitted a similar function to $\mathrm{C}$ oxidation rates in Washington state cortinental margin scdiments and found an exponential factor of $-0.91 \pm 0.10$, implying much stronger attenuation of the rates with depth. Thus, our measured COR at 2,000 m was 2.5 times higher than that predicted by their coefficient.

Pathways of $\mathrm{C}$ mineralization-The oxidation of organic matter in the sea floor proceeds through a chain of biologically catalyzed processes, including hydrolysis, fermentation, and respiration. Under anoxic conditions, the production of $\Sigma \mathrm{CO}_{2}$ is not necessarily entirely coupled to respiration since some $\Sigma \mathrm{CO}_{2}$ may be released during fermentation with concomitant production of reduced substances such as ethanol or $\mathrm{H}_{2}$ (e.g. Schink 1988). Because these fermentation products are favorable substrates for anaerobic respiratory bacteria, they are kept at low concentrations by rapid consumption (Sørensen et al. 1981; Parkes et al. 1989) and, overall, the oxidation of $\mathrm{C}$ is balanced by the reduction of the inorganic oxidants $\mathrm{O}_{2}$, $\mathrm{NO}_{3}{ }^{-}$, oxides of $\mathrm{Mn}$ and $\mathrm{Fe}$, and $\mathrm{SO}_{4}{ }^{2-}$ (see also Westrich 1983). In addit on to the oxidative pathways of $\mathrm{C} \mathrm{min-}$ eralization, net $\mathrm{SCO}_{2}$ production in sediments may result from methanogenesis, which does not represent a net $\mathrm{C}$ oxidation. Generally, however, $\mathrm{SO}_{4}{ }^{2-}$-reducing bacteria outcompete methanogens for common substrates so that methanogenesis only becomes significant deeper in marine sediments, where $\mathrm{SO}_{4}{ }^{2-}$ is depleted (e.g. Martens and Klump 1984). We therefore did not expect this process to affect our $\Sigma \mathrm{CCO}_{2}$ measurements, which was confirmed by direct measurements of methanogenesis at stations $\mathrm{C} 7$ and $\mathrm{C} 18$ that showed rates $<1 \%$ of $\Sigma \mathrm{CO}_{2}$ production ( $\mathrm{T}$. G. Ferdelman $\epsilon t$ al. in prep.).

The $\Sigma \mathrm{CO}_{2}$ production associated with $\mathrm{SO}_{4}{ }^{2-}$ reduction can be calculated from the $\mathrm{SO}_{4}{ }^{2-}$ reduction rates and the overall stoichiometry of $\mathrm{C}_{\text {org }}$ oxidation with $\mathrm{SO}_{4}{ }^{2-}$. In 
conversions of oxidant consumption to $\mathrm{C}$ oxidation in marine sediments, an oxidation state of 0 , as for carbohydrates, is commonly used for the $\mathrm{C}$ being oxidized (e.g. Froelich et al. 1979; Reimers et al. 1992; Canfield et al. 1993a). For $\mathrm{SO}_{4}{ }^{2-}$ reduction, this corresponds to the reaction

$$
2 \mathrm{CH}_{2} \mathrm{O}+\mathrm{SO}_{4}{ }^{2-} \rightarrow 2 \mathrm{HCO}_{3}^{-}+\mathrm{H}_{2} \mathrm{~S} .
$$

The use of this stoichiometry is supported by the mean ratio of $\Sigma \mathrm{CO}_{2}$ production to $\mathrm{SO}_{4}{ }^{2-}$ depletion of $2.0: 1$ measured during the prolonged incubations, where $\mathrm{H}_{2} \mathrm{~S}$ accumulation signaled the depletion of reactive $\mathrm{Fe}$ phases (Canfield et al. 1992) and $\mathrm{SO}_{4}{ }^{2-}$ reduction could thus be assumed to be the only process contributing to $C$ oxidation (Table 7). We have used this ratio to calculate $\Sigma \mathrm{CO}_{2}$ production from the $\mathrm{SO}_{4}{ }^{2-}$ reduction rates of the short-term incubations. The use of a 2.0:1 ratio is also supported by studies in Long Island Sound sediments (Westrich 1983) and sapropels from Bermuda (Boudreau et al. 1992), whereas a $\Sigma \mathrm{CO}_{2}: \mathrm{SO}_{4}{ }^{2-}$ ratio of $1.7: 1$ has been reported for $\mathrm{SO}_{4}{ }^{2-}$ reduction in Cape Lookout Bight sediment (Alperin et al. 1994). A recent global estimate of the $\mathrm{C}_{\mathrm{org}}: \mathrm{O}_{2}$ reaction ratio in pelagic remineralization (Anderson and Sarmiento 1994) corresponded to a $\mathrm{C}_{\text {org }}$ oxidation state of -0.7 , which also translates to a $\mathrm{C}_{\text {org }}$ : $\mathrm{SO}_{4}{ }^{2-}$ ratio of $1.7: 1$. This ratio would correspond to a $15 \%$ lower contribution of $\mathrm{SO}_{4}{ }^{2-}$ reduction to C oxidation than would the measured value of $2.0: 1$.

The importance of $\mathrm{SO}_{4}{ }^{2-}$ reduction and, by difference, of other $\mathrm{e}^{-}$acceptors in total $\mathrm{C}$ oxidation can be determined by comparing $\mathrm{COR}_{\text {total }}$ to the calculated $\mathrm{C}$ oxidation by $\mathrm{SO}_{4}{ }^{2-}$ reduction ( $\mathrm{COR}_{\text {sulfate }}$; Fig. 16). At $\mathrm{C} 41$, the large excess $\Sigma \mathrm{CO}_{2}$ production in the surface intervals indicates that $\mathrm{e}^{-}$acceptors other than $\mathrm{SO}_{4}{ }^{2-}$ were important at this site (Fig. 16). The excess decreased with depth, and by $8-10 \mathrm{~cm}, \mathrm{SO}_{4}{ }^{2-}$ reduction accounted for all $\Sigma \mathrm{CO}_{2}$ accumulation. At $\mathrm{C} 40, \mathrm{COR}_{\text {surate }}$ was relatively more important, and at all the shelf sites, $C O R_{\text {sulfate }}$ was close to $\mathrm{COR}_{\text {total }}$ at all depths. To further deduce the relative importance of the $\mathrm{C}$ oxidation pathways, we followed a scheme similar to that introduced by Canfield et al. $(1993 b)$, as summarized in Table 9. The slope and shelf stations are discussed scparately since the mass occurrence of Thioploca at the shelf stations requires special considerations.

Slope stations - The depth intervals where oxic respiration and denitrification could be of importance are identified from the distributions of $\mathrm{O}_{2}$ and $\mathrm{NO}_{3}{ }^{-}$. At the slope stations $\mathrm{C} 40$ and $\mathrm{C} 41$, with the limitation of the $0.5-\mathrm{cm}$ depth resolution of our bag incubations, these intervals included $0-1-\mathrm{cm}$ depth (Fig. 3). At C41, redox cycling of $\mathrm{Mn}$ in this interval was demonstrated both by the depth distributions of Mn species (Fig. 6) and by the accumulation of $\mathrm{Mn}^{2+}$ during incubations (Fig. 15). At both sites, sulfate reduction was observed in the surface sections, and at $\mathrm{C} 40, \mathrm{Fe}^{2+}$ also accumulated (Figs. 13, 15). The depletion of $\mathrm{O}_{2}$ and $\mathrm{NO}_{3}{ }^{-}$during incubation, however, likely stimulated reduction of $\mathrm{Mn}, \mathrm{Fe}$, and $\mathrm{SO}_{4}{ }^{2-}$. Previous studies of sediments with similar chemical zonation have concluded that $\mathrm{Mn}$ reduction was mainly

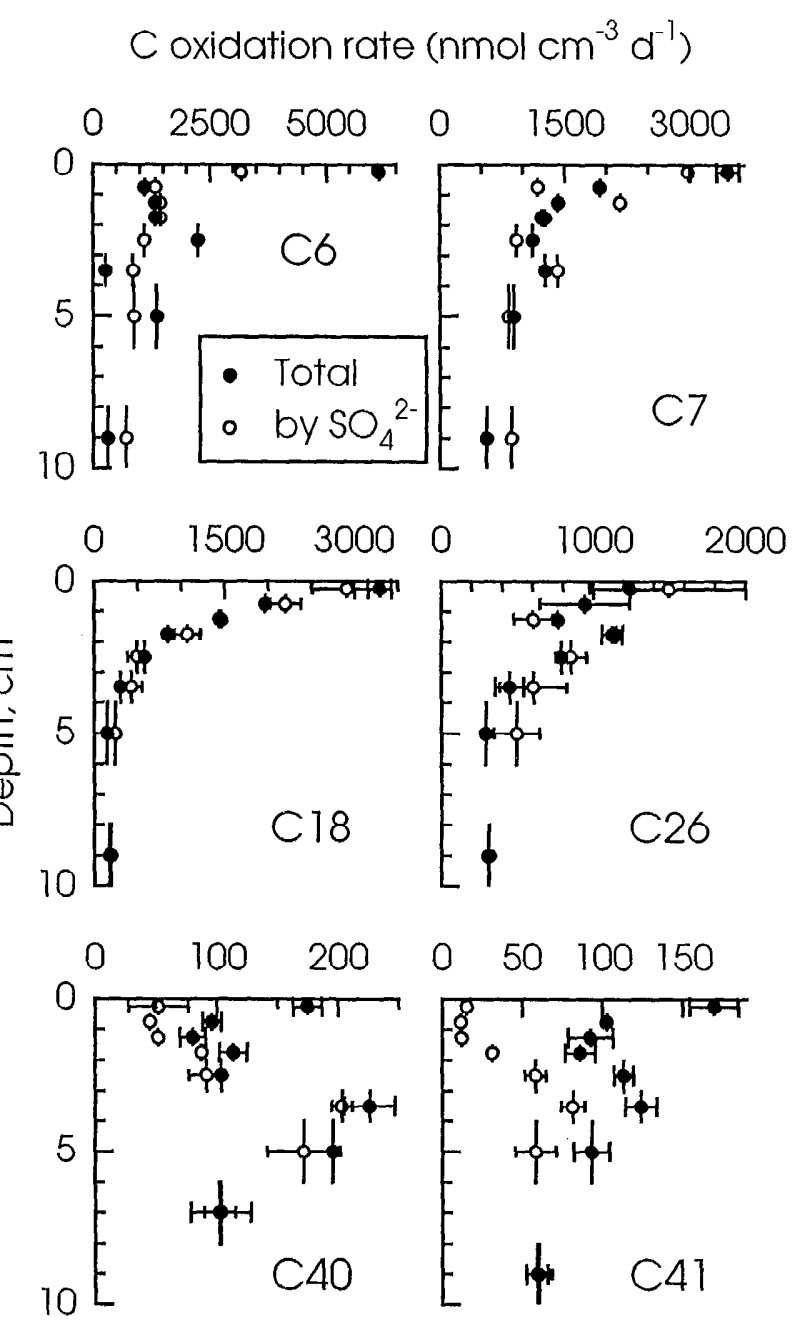

Fig. 16. Comparison of total observed carbon oxidation rates $\left( \pm \mathrm{SE}\right.$ ) to $\mathrm{C}$ oxidation due to $\mathrm{SO}_{4}{ }^{2-}$ reduction (error bars span duplicate determinations). No crrors were calculated for $\mathrm{C} 6$ or $\mathrm{SO}_{4}{ }^{2-}$ reduction rates at $\mathrm{C}$.

associated with the reoxidation of reduced $\mathrm{Fe}$ and $\mathrm{S}$ (Canfield et al. 1993b; Aller 1994; Thamdrup et al. 1994a). This could also be the case at $\mathrm{C} 41$, where rapid reoxidation of $\mathrm{Fe}^{2+}$ with Mn oxides (Postma 1985) may have masked Fe reduction. The low levels of $\mathrm{Mn}$ encountered throughout the transect probably resulted from $\mathrm{Mn}$ mobilization from the sediments underlying $\mathrm{O}_{2}$-depleted bottom water (Thamdrup et al. 1994b). From these considerations it follows that the pathways of $\mathrm{C}$ oxidation in the surface interval cannot be individually quantified.

Of the total C oxidation, the $0-1-\mathrm{cm}$ interval accounted for $12 \%$ at $\mathrm{C} 40$ and $15 \%$ at $\mathrm{C} 41$ (Fig. 11), and we tentatively use these values as estimates of the combined contribution of oxic respiration, denitrification, and, at $\mathrm{C} 41$, dissimilatory $\mathrm{Mn}$ reduction to mineralization (Table 10). This rests on the assumption, also made by Canfield et al. (1993a), that the total $\mathrm{C}$ oxidation rate was not affected by the depletion of $\mathrm{O}_{2}$ and $\mathrm{NO}_{3}{ }^{-}$. This assumption is supported by the observation that relatively fresh organic matter appears to decay at approximately similar rates under oxic and anoxic $\left(\mathrm{SO}_{4}{ }^{2-}\right.$-reducing) conditions, 
Table 9. General scheme for deducing pathways of carbon oxidation.

\begin{tabular}{|c|c|}
\hline Step & Comment \\
\hline Depth distribution of $\Sigma \mathrm{CO}_{2}$ production & Total $\mathrm{C}$ oxidation rates \\
\hline $\mathrm{CaCO}_{3}$ precipitation/dissolution & Potential correction to $\mathrm{C}$ oxidation rates \\
\hline Depth distribution of $\mathrm{NH}_{4}{ }^{+}$accumulation & Check on C metabolism \\
\hline $\mathrm{O}_{2}$ and $\mathrm{NO}_{3}^{-}$distributions & Max. depths of oxic respiration and denitrification \\
\hline Combined $\mathrm{C}$ oxidation by $\mathrm{O}_{2}$ and $\mathrm{NO}_{3}^{-}$estimate & $\Sigma \mathrm{CO}_{2}$ production in $\mathrm{O}_{2} / \mathrm{NO}_{3}^{-}$zone \\
\hline Combined $\mathrm{C}$ oxidation by $\mathrm{Mn}, \mathrm{Fe}$, and $\mathrm{SO}_{4}{ }^{2-}$ reduction & $\Sigma \mathrm{CO}_{2}$ production below $\mathrm{O}_{2} / \mathrm{NO}_{3}{ }^{-}$zone \\
\hline $\mathrm{SO}_{4}{ }^{2-}$ reduction rates & Direct determination \\
\hline $\mathrm{CO}_{2}$ production by $\mathrm{SO}_{4}^{2-}$ reduction & From stoichiometry \\
\hline Combined $\mathrm{C}$ oxidation by $\mathrm{Mn}$ and $\mathrm{Fe}$ reduction & Difference between total and $\mathrm{SO}_{4}{ }^{2-}$-coupled $\mathrm{C}$ oxidation \\
\hline Separation of $\mathrm{Mn}$ and $\mathrm{Fe}$ reduction & From oxide distributions and accumulation of $\mathrm{Mn}^{2+}$ and $\mathrm{Fe}^{2+}$ \\
\hline
\end{tabular}

but as mineralization proceeds, the oxic pathway may become relatively faster (cf. Canfield 1993; Kristensen et al. 1995). The efficiency of $\mathrm{Mn}$ and Fe reduction in this context has not been specifically investigated, and further investigations are clcarly rcquired to test our assumption. To better constrain the contribution from oxic respiration, measurements like the present may be combined with determination of benthic fluxes (Canfield et al. 1993a). Unfortunately, such determinations were not available for the slope sites.

While the relative importance of the $\mathrm{e}^{-}$acceptors near the sediment surface cannot be determined, Fe(III) was the only available oxidant below $1 \mathrm{~cm}$ other than $\mathrm{SO}_{4}^{2-}$. The comparison of total and $\mathrm{SO}_{4}{ }^{2-}$ reduction-coupled $\mathrm{C}$ oxidation (Fig. 16) showed a distinct excess $\mathrm{C}$ oxidation to $6-\mathrm{cm}$ depth at $\mathrm{C} 41$ and to $2 \mathrm{~cm}$ at $\mathrm{C} 40$, with a slight excess extending to $6 \mathrm{~cm}$. There was close agreement between excess $\mathrm{C}$ oxidation, the distribution of poorly crystalline $\mathrm{Fe}(\mathrm{III})$ (Fig. 7), and the depths at which dissolved $\mathrm{Fe}^{2+}$ accumulated during the incubations (Fig. 15). In the presence of poorly crystalline $\mathrm{Fe}$ hydroxides, but not crystalline forms, Fc-reducing bacteria have been shown to outcompete $\mathrm{SO}_{4}{ }^{2-}$-reducing bacteria for common substrates (Lovley and Phillips 1987). Subtraction

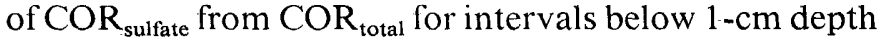
(Fig. 16) gives excess $C$ oxidation rates that correspond to 12 and $29 \%$ of total $C$ oxidation at $C 40$ and $C 41$, respectively (Table 10 ), or 13 and $34 \%$ of the C oxidation in the anoxic portions, which we attribute to Fe reduction. As mentioned above, it is possible that Fe reduction also contributed to $C$ oxidation within the upper $0-1-\mathrm{cm}$ interval, at least at $\mathrm{C} 40$, but this contribution cannot be quantified. Although Fe reduction cannot be measured directly, we con slude that this process was significant for $\mathrm{C}$ oxidation at both slope sites.

The rates of $\mathrm{Fe}^{2+}$ (and $\mathrm{Mn}^{2+}$ ) accumulation at $\mathrm{C} 40$ and $\mathrm{C} 41$ were small in comparison to $\mathrm{C}$ oxidation rates. Canfield et al. $(19,3 b)$ showed that accumulation rates of pore-water $\mathrm{Mn}^{2+}$ and $\mathrm{Fe}^{2+}$ strongly underestimate rates of $\mathrm{Mn}$ and $\mathrm{Fe}$ reduction because of adsorption or precipitation of the reduced species. We did not determine the adsorptive charactcristics of the Chilean scdiments, but the Fe extractions demonstrate depthwise accumulation of most of the Fe(II) in a solid, nonsulfidic phase (Figs. $7,8)$. Owing tc the high initial Fe(II) concentrations, it was not possible to quantify changes in the solid phases over the short-term incubations.

The maintenance of high $\mathrm{Fe}$ (or $\mathrm{Mn}$ ) reduction rates depends on coritinuous mixing of metal oxides and fresh organic matter into the sediments through bioturbation or other mixing processes (Aller 1990; Canfield et al. $1993 b$ ). Because most $\mathrm{Fe}(\mathrm{II})$ is also particle-bound, mixing is also important for its upward transport to allow $\mathrm{Fe}$ oxidation at the surface, as demonstrated by the opposed gradients of Fe(II) and Fe(III) (Fig. 7). The relative constancy of both $\mathrm{C}_{\text {org }}$ and $\mathrm{COR}_{\text {total }}$ with depth at the slope sites also indicated rapid mixing of organics into the sediments (Figs. 2, 16).

We have no quantitative estimates of the sediment mixing, but ${ }^{210} \mathrm{~Pb}$ distributions showed mixing to at least $5-\mathrm{cm}$ depth at C41 and to $4 \mathrm{~cm}$ at C.40 (M. A. Salamanca pers. comm.). It is thus likely that deeper mixing at $\mathrm{C} 41$, in conjunction with lower total $\mathrm{C}$ mineralization rates, resulted in a larger contribution from Fe reduction there

Table 10. Rates of carbon oxidation $\left(\mathrm{mmol} \mathrm{m}^{-2} \mathrm{~d}^{-1}\right)$ and relative importance $(\%)$ of carbon oxidation pathways (nd-not detected).

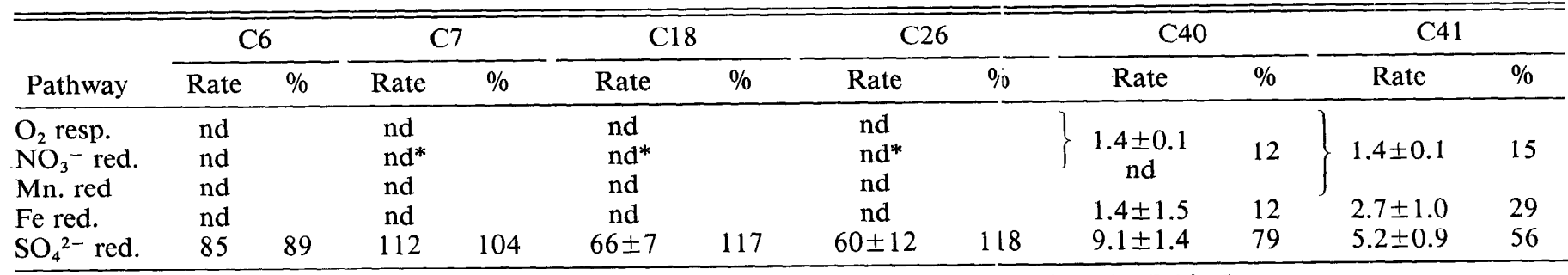

See text for principles of calculation. Errors have bcen propagated as SD from those given in Table 5 .

* Nitrate consumption was observed (Table 8 ) but did not appear directly couple 1 to C oxidation (see text). 
than at $\mathrm{C} 40$. The turnover times of the poorly crystalline $\mathrm{Fe}(\mathrm{III})$ pools through $\mathrm{Fe}$ reduction were $70 \mathrm{~d}$ at $\mathrm{C} 40$ and $71 \mathrm{~d}$ at $\mathrm{C} 41$. These values are similar to those calculated for the Skagerrak sediments, where Fc reduction was very important (70-79 d; Canficld et al. 1993b). The surface concentration of oxalate-extractable Fe (Fig. 7) combined with a sediment accumulation rate of $0.15 \mathrm{~cm} \mathrm{yr}^{-1}(\mathrm{M}$. A. Salamanca pers. comm.) yields a delivery flux of poorly crystalline Fe of $0.14 \mathrm{mmol} \mathrm{m}^{-2} \mathrm{~d}^{-1}$ for both sites. Thus, on average, each $\mathrm{Fe}$ atom was reduced and reoxidized (rate of reduction/delivery flux) 31 and 77 times before burial at $\mathrm{C} 40$ and $\mathrm{C} 41$, respectively.

The calculations above concern only Fe cycling coupled to $\mathrm{C}$ oxidation. The absence of $\mathrm{H}_{2} \mathrm{~S}$ from the pore water, in spite of active $\mathrm{SO}_{4}{ }^{2-}$ reduction (Figs. 3,13 ), and the accumulation of iron sulfides, mainly $\mathrm{FeS}_{2}$ (Fig. 8), indicate additional coupling of the $\mathrm{Fe}$ and $\mathrm{S}$ cycles. For other coastal sediments, it has been shown that reaction with free $\mathrm{Fe}(\mathrm{III})$ oxides may buffer pore-water $\mathrm{H}_{2} \mathrm{~S}$ below the detection limit in the presence of $\mathrm{SO}_{4}{ }^{2-}$ reduction (Goldhaber and Kaplan 1974; Canfield 1989; Thamdrup et al. 1994a). Hydrogen sulfide reacts with Fe oxides by the overall reaction (Pyzik and Sommer 1981)

$$
3 \mathrm{H}_{2} \mathrm{~S}+2 \mathrm{FeOOH} \rightarrow 2 \mathrm{FeS}+\mathrm{S}^{0}+4 \mathrm{H}_{2} \mathrm{O} .
$$

If all $\mathrm{H}_{2} \mathrm{~S}$ produced reacted according to this equation, the $\mathrm{SO}_{4}{ }^{2-}$ reduction rates measured at $\mathrm{C} 40$ and $\mathrm{C} 41$ would correspond to reactions of 3.0 and $1.7 \mathrm{mmol} \mathrm{Fe}$ (III) $\mathrm{m}^{-2}$ $\mathrm{d}^{-1}$, respectively, which are equivalent to 54 and $16 \%$ of the calculated organotrophic Fe reduction (Table 10). Hydrogen sulfide reacts most rapidly with poorly crystalline Fe oxides, but crystalline oxides also react (Canfield 1989; Canfield et al. 1992). A role for crystalline Fe oxides was indicated at the slope sites, where $\mathrm{H}_{2} \mathrm{~S}$ was not detected to at lcast 20-cm depth (Fig. 3), far beyond the penctration depth of the poorly crystalline Fe oxides (Fig. 7). Thus, because of the coupling to the $\mathrm{S}$ cycle, the turnover of the poorly crystalline Fe(III) pool should be somewhat faster than calculated from $\mathrm{C}$ oxidation alone.

Shelf stations-Bottom-water anoxia on the shelf excluded oxic respiration from the sediments. However, this situation represented a seasonal extreme. The cruise took place in late summer, which is when Thioploca mats have their widest distribution and the $\mathrm{O}_{2}$ minimum zone reaches its shallowest depth (V. A. Gallardo pers. comm.). Bottom-water anoxia was documented in several measurements between 12 and 24 March (J. K. Gundersen and R. N. Glud pers. comm.), suggesting that the depletion lasted for up to 2 wecks. Still, juvenile squat lobsters and polychaetes survived at the sediment surface. The Thioploca-covered shelf area is the nurseryground of the squat lobster $P$. monodon, and an adaptation to low $\mathrm{O}_{2}$ levels might reduce predation of the juveniles (Roa et al. 1995). We must therefore assume that absence of $\mathrm{O}_{2}$ was a transient phenomenon that coincided with the cruise and may be triggered by a pulse of primary production associated with an upwelling event. Hence, our rate measurements were likely close to the summer maximum, and the completc lack of $\mathrm{O}_{2}$ at the sediment surface was not typical for the area. We cannot speculate on the importance of $\mathrm{O}_{2}$ in $\mathrm{C}$ cycling during times of the year when $\mathrm{O}_{2}$ is present in high concentrations in the overlying water.

A benthic $\mathrm{NO}_{3}{ }^{-}$uptake of $2.1 \mathrm{mmol} \mathrm{m} \mathrm{m}^{-2} \mathrm{~d}^{-1}$ was measured in situ at C18 during the cruise (Fossing et al. 1995; R. N. Glud et al. in prep.). If we assume denitrification according to

$$
\begin{aligned}
5 \mathrm{CH}_{2} \mathrm{O}+4 \mathrm{NO}_{3}{ }^{-} \rightarrow & 5 \mathrm{HCO}_{3}^{-}+2 \mathrm{~N}_{2} \\
& +2 \mathrm{H}_{2} \mathrm{O}+\mathrm{H}^{+},
\end{aligned}
$$

this uptake corresponds to a $\mathrm{C}$ oxidation of $2.6 \mathrm{mmol}$ $\mathrm{m}^{-2} \mathrm{~d}^{-1}$, or $<5 \%$ of the total $\mathrm{C}$ oxidation rate (Table 5 ). However, determination of the fate of $\mathrm{NO}_{3}{ }^{-}$in the shelf sediments and its role in $\mathrm{C}$ oxidation is complicated by the large accumulation of $\mathrm{NO}_{3}{ }^{-}$in the Thioploca filaments. Hence, when ${ }^{15} \mathrm{NO}_{3}{ }^{-}$was added to the overlying water, essentially all of it was taken up and stored by the Thioploca and was not used immediately for C mineralization (L. P. Nielsen pers. comm.; R. N. Glud ct al. in prep.). Thus, we assume that the large $\mathrm{NO}_{3}{ }^{-}$pool in the sediments was metabolized by Thioploca and that the sediment $\mathrm{NO}_{3}{ }^{-}$- consumption was not directly coupled to C oxidation, because the organism is presumed to couple $\mathrm{NO}_{3}{ }^{-}$reduction to oxidation of $\mathrm{H}_{2} \mathrm{~S}$ (Fossing ct al. 1995).

There was a close match between the measured $\mathrm{C}$ oxidation rates and the rates attributable to $\mathrm{SO}_{4}{ }^{2-}$ reduction on the shelf (Fig. 16). A very close match was found at $\mathrm{C} 18$; also at $\mathrm{C} 26$, the mean $\mathrm{COR}_{\text {sulfate }}$ agreed well with $\mathrm{COR}_{\text {total }}$, although the comparison at $\mathrm{C} 26$ was blurred somewhat by the differences between the two $\mathrm{SO}_{4}{ }^{2-}$ reduction rate determinations. The single $\mathrm{COR}_{\text {suffate }}$ determination at $\mathrm{C} 7$ similarly varied around $\mathrm{COR}_{\text {total }}$. The measurements at $\mathrm{C} 6$ were associated with more, albeit undetermined, uncertainty than at the other sites because of the truncated incubation, but the general similarity of $\mathrm{COR}_{\text {total }}$ and $\mathrm{COR}_{\text {sulfate }}$ was clear. Thus, as is consistent with solid-phase metal distributions and incubation results, no role for dissimilatory $\mathrm{Mn}$ reduction was indicated and only a small role for Fe reduction seems likely (Table 4, Fig. 7). Even if all $\mathrm{C}$ oxidation in the upper 2 $\mathrm{cm}\left(40,38\right.$, and $20 \mathrm{mmol} \mathrm{m}^{-2} \mathrm{~d}^{-1}$ at $\mathrm{C} 7, \mathrm{C} 18$, and $\left.\mathrm{C} 26\right)$ were through $\mathrm{Fe}$ reduction, the depletion time for poorly crystalline $\mathrm{Fe}$ (III) pools would be $\sim 20 \mathrm{~h}$ at all sites (i.e. not much shorter than the entire short-term incubations). Thus, the lack of importance for Fe reduction was not due to a rapid initial depletion of Fe(III) during the incubations. Possible coupling of the $\mathrm{Fe}$ and $\mathrm{S}$ cycles is discussed below.

Nitrogen cycling - The ability of Thioploca filaments to concentrate $\mathrm{NO}_{3}{ }^{-}$in their central vacuole, together with the high population density of this organism, led to a unique $\mathrm{N}$ cycle in the shelf sediments (Fossing et al. 1995) with possible implications for other element cycles. Results from both whole-core squeezing and from extraction of dried sediment demonstrated $\mathrm{NO}_{3}{ }^{-}$contents up to 100 times larger than those of the pore water (Table 2). Analysis of a sample of sheathed Thioploca bundles confirmed their high $\mathrm{NO}_{3}{ }^{-}$content (Table 3), and this value of 0.44 
mmol $\mathrm{g}^{-1}$ dry wt combined with biomass maxima of sheathed Thioploca of 0.3-1.5 mg dry $\mathrm{w}_{\mathrm{cm}}^{-3}$ found near the surface at C7-C26 (Schulz 1995) yiclds $\mathrm{NO}_{3}{ }^{-}$contents of $0.13-0.66 \mu \mathrm{mol} \mathrm{cm} \mathrm{cm}^{-3}$, equivalent to pore-water concentrations of 120-600 $\mu \mathrm{M}$. In an independent determination of biovolumes of Thioploca filaments (excluding sheaths), Schulz et al. (1996) found sharp maxima at $0-0.5-\mathrm{cm}$ depth, with the highest value at C7 $\left(12 \mathrm{~mm}^{3}\right.$ $\mathrm{cm}^{-3}$ ), and estimated that the vacuole made up $85 \%$ of this volume. In conjunction with an average $\mathrm{NO}_{3}^{-}$concentration in the vacuoles of $200 \mathrm{mM}$ (L. P. Nielsen pers. comm.), this corresponds to a scdiment concentration of $2 \mu \mathrm{mol} \mathrm{cm}^{-3}$ (or $2 \mathrm{mM}$ ). Both of these approaches give $\mathrm{NO}_{3}{ }^{-}$concentrations that are consistent with the sediment data, including the maximum at $\mathrm{C} 7$.

Although the depth-integrated $\mathrm{NO}_{3}{ }^{-}$consumption rates as measured during the incubations were low relative to the total sediment metabolism, they were high compared to denitrification rates from other offshore sediments (Table 8; Canfield 1993). This difference was further accentuated by the fact that, as apparent from the time course at $\mathrm{C} 18$ (Fig. 14), the mean $\mathrm{NO}_{3}{ }^{-}$consumption rates during the incubations probably underestimated the initial rates. There was, however, a good agreement between the depth-integrated $\mathrm{NO}_{3}{ }^{-}$consumption rate (Table 8 ) and the sediment $\mathrm{NO}_{3}{ }^{-}$uptake determined in situ at $\mathrm{C} 18$ (2.1 mmol m $\mathrm{m}^{-2} \mathrm{~d}^{-1}$; Fossing et al. 1995). The benthic $\mathrm{NO}_{3}^{-}$ uptake might, however, vary strongly in time, since this uptake seems to be regulated by Thioploca in a complex manner (Fossing et al. 1995; Hüttel et al. 1996).

It has been proposed that Thioploca performs $\mathrm{H}_{2} \mathrm{~S}$ oxidation with $\mathrm{NO}_{3}{ }^{-}$in two steps (Fossing et al. 1995):

$$
\begin{aligned}
5 \mathrm{H}_{2} \mathrm{~S}+2 \mathrm{NO}_{3}{ }^{-}+2 \mathrm{H}^{+} & \rightarrow 5 \mathrm{~S}^{0}+\mathrm{N}_{2}+6 \mathrm{H}_{2} \mathrm{O} \\
6 \mathrm{NO}_{3}{ }^{-}+5 \mathrm{~S}^{0}+2 \mathrm{H}_{2} \mathrm{O} & \rightarrow 3 \mathrm{~N}_{2}+5 \mathrm{SO}_{4}{ }^{2-}+4 \mathrm{H}^{+} \\
\Sigma: 5 \mathrm{H}_{2} \mathrm{~S}+8 \mathrm{NO}_{3}{ }^{-} & \rightarrow 5 \mathrm{SO}_{4}{ }^{2-}+4 \mathrm{~N}_{2}+2 \mathrm{H}^{+}+4 \mathrm{H}_{2} \mathrm{O}
\end{aligned}
$$

The assumption that $\mathrm{S}^{\circ}$ is an intermediate in $\mathrm{H}_{2} \mathrm{~S}$ oxidation by Thioploca arises from the observation of $\mathbf{S}^{0}$ globules in the cells (Maier and Gallardo 1984a,b). We also found a high $\mathrm{S}$ content in Thioploca (Table 3), which we assume represents mainly $S^{0}$. In the sediment, this $S$ content was equivalent to maximum concentrations of $0.5-2.7 \mu \mathrm{mol} \mathrm{cm} \mathrm{cm}^{-3}$ that were determined by using the biomass estimates of Schulz (1995, see above). Thus, Thioploca accounted for up to $50 \%$ of the total sediment

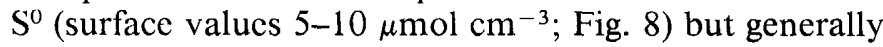
accounted for less than this.

The possible rates of $\mathrm{H}_{2} \mathrm{~S}$ oxidation to $\mathrm{SO}_{4}{ }^{2-}$ (Eq. 7) that can be calculated from the depth-integrated $\mathrm{NO}_{3}{ }^{-}$ consumption rates (Table 8 ) correspond to 4,5 , and $2 \%$ of the $\mathrm{SO}_{4}{ }^{2-}$ reduction rates at $\mathrm{C} 7, \mathrm{C} 18$, and $\mathrm{C} 26$, respectively. Thus, only a small part of the $\mathrm{H}_{2} \mathrm{~S}$ produced during the incubations could have been reoxidized with $\mathrm{NO}_{3}{ }^{-}$, except possibly in the extremely $\mathrm{NO}_{3}{ }^{-}$-rich $0-0.5-$ $\mathrm{cm}$ interval at $\mathrm{C} 7$.

The metabolic characteristics of Thioploca have not been determined directly, and it is possible that the observed $\mathrm{NO}_{3}{ }^{-}$consumption during our incubations was due to reactions other than complete oxidation of $\mathrm{H}_{2} \mathrm{~S}$. Thus, the steps suggested for the oxidation (Eq. 5 and 6) need not be closely linked. Partial oxidation to $S^{0}$ could have been preferred during the incubations, in which case 4 times more $\mathrm{H}_{2} \mathrm{~S}$ would have been reacted than by complete oxidation (Eq. 7). If the $\mathrm{S}: \mathrm{NO}_{3}{ }^{-}$ratio of the Thioploca sample of $4: 1$ (Table 3 ) was representative of the Thioploca composition in general, the $\mathrm{NO}_{3}^{-}$consumption could have been entirely coupled to oxidation of the internal $S^{0}$ pool (Eq. 6). Furthermore, it is possible that $\mathrm{NO}_{3}{ }^{-}$is reducec to $\mathrm{NH}_{4}{ }^{+}$rather than to $\mathrm{N}_{2}$, which would increase the oxidative capacity of the $\mathrm{NO}_{3}{ }^{-}$pool by $60 \%$ $\left(\mathrm{NO}_{3}^{-}+5 \mathrm{e}^{-} \rightarrow 1 / 2 \mathrm{~N}_{2} ; \mathrm{NO}_{3}^{-}+8 \mathrm{e}^{-} \rightarrow \mathrm{NH}_{4}^{+}\right)$. This pathway could contribute to the low $\Sigma \mathrm{CO}_{2}: \mathrm{NH}_{4}{ }^{+}$accumulation ratios near the surface at $\mathrm{C} 7$ and $\mathrm{C} 18$ (Table 6) and could also explain the high initial concentration of $\mathrm{NH}_{4}{ }^{+}$relative $t_{1} \mathrm{\Sigma CO}_{2}$ at those stations (Fig. 3). At C26 on the other hand, high $\Sigma \mathrm{CO}_{2}: \mathrm{NH}_{4}{ }^{+}$accumulation ratios coincided with aigh $\mathrm{NO}_{3}{ }^{-}$consumption rates (Table 8 ). Hence, nonsystematic liberation ratios of $\Sigma \mathrm{CO}_{2}$ to $\mathrm{NH}_{4}{ }^{+}$ in $\mathrm{NO}_{3}{ }^{-}$-rich samples could result from differences in the organic matter jeing mineralized and make conclusions on the product of $\mathrm{NO}_{3}{ }^{-}$reduction difficult to support.

Fate of $\mathrm{H}_{2} \mathrm{~S}$-- We were surprised to find the combination of extreme rates of $\mathrm{SO}_{4}{ }^{2-}$ reduction and low levels of $\mathrm{H}_{2} \mathrm{~S}$ in all sinelf sediments except $\mathrm{C} 6$ (Fig. 3). With $\mathrm{SO}_{4}{ }^{2-}$ reduction rates up to $1,500 \mathrm{nmol} \mathrm{cm}{ }^{-3} \mathrm{~d}^{-1}$, the maintenance of $\mathrm{H}_{2} \mathrm{~S}$ below detection $(<1 \mu \mathrm{M})$ requires a half-life of $<1 \mathrm{~min}$. The subsurface maxima of a few micromoles observed in one core from $\mathrm{C} 18$ thus indicated a very delicate balance of production and consumption. As discussed atove, the $\mathrm{NO}_{3}{ }^{-}$consumption rates (Table 8) were too small for oxidation with $\mathrm{NO}_{3}^{-}$(Eq. 5 or 7 ) to explain the "missing" $\mathrm{H}_{2} \mathrm{~S}$ during the incubations.

The dominarce by $\mathrm{Fe}^{2+}$ in the pore waters (Fig. 3) and the accumulation of FeS during the prolonged incubations at $\mathrm{C} 7$ and $\mathrm{C} 18$ demonstrated that $\mathrm{Fe}$ minerals were important $\mathrm{H}_{2} \mathrm{~S}$ scavengers as they are in other, less active sediments, such as $\mathrm{C} 40$ and $\mathrm{C} 41$. Throughout the shortterm incubatior:s, sediments remained $\mathrm{H}_{2} \mathrm{~S}$-free, with $\mathrm{H}_{2} \mathrm{~S}$ accumulation and $\mathrm{Fe}^{2+}$ depletion shortly after the bcginning of the proionged incubations (i.c. after $\sim 2 \mathrm{~d}$ ). With $\mathrm{H}_{2} \mathrm{~S}$ removal according to Eq. $4,25-38 \mathrm{mmol} \mathrm{Fe}(\mathrm{III}) \mathrm{m}^{-2}$ were required to scavenge the $\mathrm{H}_{2} \mathrm{~S}$ produced at the mean $\mathrm{SO}_{4}{ }^{2-}$ reduction rates (Table 5) during the short-term incubations at $\mathrm{C} 7, \mathrm{C} 18$, and $\mathrm{C} 26$. This corresponds to $25-40 \%$ of the poorly crystalline Fe(III) fraction (Table 4). In addition to reaction with $\mathrm{Fe}$ (III), $\mathrm{H}_{2} \mathrm{~S}$ may also be removed by precipitation with $\mathrm{Fe}(\mathrm{II})$, particularly the quantitatively significant pool of nonsulfide Fe(II) found in the solid phase (compare Figs. 7, 8; Thamdrup et al. 1994a).

If $\mathrm{Fe}$ phases were as important scavengers of $\mathrm{H}_{2} \mathrm{~S}$ in situ as was the case during our incubations, this would imply that we sampled both $\mathrm{C} 7$ and $\mathrm{C} 18$ just $2 \mathrm{~d}$ before a buildup of $\mathrm{H}_{2} \mathrm{~S}$ (assuming that the $\mathrm{Fe}$ pool not was rapidly recycled in situ). In the absence of $\mathrm{O}_{2}$ and $\mathrm{Mn}$ oxides, reoxidation of dissolved or particulate $\mathrm{Fe}(\mathrm{II})$ could 
only be by $\mathrm{NO}_{3}^{-}$. This process has been implied in hemipelagic sediments (Froelich et al. 1979) and has recently been demonstrated in pure cultures of marine bacteria (Straub et al. 1996). As argucd above, however, the sediment $\mathrm{NO}_{3}{ }^{-}$uptake mainly went to Thioploca, and this organism is not considered an Fe oxidizer. Thus, rapid in situ cycling of the small Fe(III) fraction was unlikely at the time of the cruise. Eleven days passed between the first (C18; 12 March) and last (C26; 23 March) sampling, but we did not return to the same station during this interval. Ferdelman et al. (in prep.) measured $250 \mu \mathrm{M}$ $\mathrm{H}_{2} \mathrm{~S}$ at $5-\mathrm{cm}$ depth at a station $5.6 \mathrm{~km}$ seaward of $\mathrm{C} 18$ on 22 March and $400 \mu \mathrm{M} \mathrm{H}_{2} \mathrm{~S}$ at the sediment-water interface of $\mathrm{C} 7$ on $27 \mathrm{March}, 6 \mathrm{~d}$ after our sampling. Also, strong sulfide smell has previously been reported from the surface sediments (Gallardo 1977) where we detected no $\mathrm{H}_{2} \mathrm{~S}$, so $\mathrm{H}_{2} \mathrm{~S}$ fluctuations may be common, and it is possible that a $\mathrm{H}_{2} \mathrm{~S}$ buildup was imminent.

We cannot exclude the possibility that the Thioploca in the shelf sediments contributed more significantly to $\mathrm{H}_{2} \mathrm{~S}$ scavenging in situ than was the case during the incubations. The $\mathrm{NO}_{3}{ }^{-}$uptake of the sediments could be experimentally increased well beyond the consumption rates measured during our incubations (Table 8; Fossing et al. 1995; Hüttel et al. 1996), but it is yet unknown how this uptake is regulated under natural conditions. However, the distribution of $\mathrm{SO}_{4}{ }^{2-}$ reduction rates (Fig. 13) relative to the pore-water chemistry (Fig. 3) indicates that for Thioploca to quantitatively dominate $\mathrm{H}_{2} \mathrm{~S}$ scavenging, it has to compete efficiently for $\mathrm{H}_{2} \mathrm{~S}$ at $<1 \mu \mathrm{M}$ levels with rapid reactions that involve $\mathrm{Fe}(\mathrm{III})$ and $\mathrm{Fe}(\mathrm{II})$. This would require a close association between Thioploca and the $\mathrm{H}_{2} \mathrm{~S}$-producing $\mathrm{SO}_{4}{ }^{2-}$ reduccrs.

\section{Conclusion}

Sulfate reduction was the dominant pathway of C oxidation at all sites along the transect of the Chilean margin. In the shelf sediments, sulfate reduction accounted for essentially all mincralization, whereas the importance of other $\mathrm{e}^{-}$acceptors increased down the slope, where Fe reduction became the second most important pathway, contributing $29 \%$ of C oxidation at $2,000 \mathrm{~m}$ depth (Table $10)$. Conditions on the shelf were extreme with respect to both total mineralization rates and the lack of $\mathrm{O}_{2}$ in the bottom water, whereas the slope sites fell within the typical range of coastal sediments in these respects.

Our observations, add to the small database that supports the general importance of $\mathrm{Fe}$ (and in some cases $\mathrm{Mn}$ ) reduction in sedimentary $\mathrm{C}$ oxidation. Significant Fe reduction was dependent on the presence of poorly crystalline $\mathrm{Fe}(\mathrm{III})$, which is in agreement with observations in enrichment cultures (Lovley and Phillips 1986). In sediment slurries, $\mathrm{Fe}$-reducing bacteria were found to efficiently outcompete $\mathrm{SO}_{4}{ }^{2-}$ reducers for common substrates (Lovley and Phillips 1987). In the slope sediments, however, zones of $\mathrm{Fe}$ and $\mathrm{SO}_{4}{ }^{2-}$ reduction overlapped, as has also been observed in sediments of the Norwegian Trough (Canfield et al. 1993b). Furthermore, rates of $\mathrm{SO}_{4}{ }^{2-}$ reduction increased concomitantly with the depletion of poorly crystalline Fe(III) with depth, suggesting that rates of $\mathrm{Fe}$ reduction are limited by $\mathrm{Fe}$ (III) availability in such sediments. The co-occurrence of $\mathrm{Fe}$ and $\mathrm{SO}_{4}{ }^{2-}$ reduction complicates the Fe cycle because Fe reducers must compete for $\mathrm{Fe}$ (III) with reactions that involve $\mathrm{H}_{2} \mathrm{~S}$. The outcome of this competition likely depends on the reactivity of both the available $\mathrm{Fe}(\mathrm{III})$ and $\mathrm{C}_{\text {org }}$.

Because of the particulate nature of both $\mathrm{Fe}$ and $\mathrm{Mn}$ oxides and solid $\mathrm{Fe}(\mathrm{II})$ and $\mathrm{Mn}$ (II) phases, physical mixing of sediments is necessary to recycle the metals and support significant reduction rates, and mixing additionally stimulates anaerobic mincralization by burial of reactive $C_{\text {org }}$ below the oxic zone (Aller 1990; Canficld et al. 1993b). Apart from shallow sediments where reworking by waves and currents can be important (Aller et al. 1996), bioturbation is therefore a key process in the regulation of metal reduction rates. A recent compilation of intensities and depths of mixing in scdiments from the coast to the deep sea gives a worldwide mean mixing depth of $9.8 \pm 4.5 \mathrm{~cm}$ (Boudreau 1994). Because $\mathrm{O}_{2}$ and $\mathrm{NO}_{3}{ }^{-}$typically penetrate only a few millimeters to centimeters into shelf and slope sediments (e.g. Jørgensen and Revsbech 1989; Reimers ct al. 1992; Glud ct al. 1994; Brandes and Devol 1995), significant Fe reduction could be widespread on the continental margins. However, mixing intensities, which have been estimated by assuming diffusional transport, vary by several orders of magnitude between sites, and the actual modes of mixing are poorly understood (Boudreau 1994). Further quantitative studies of bioturbation are therefore important for a better understanding of the regulation and general importance of $\mathrm{Fe}$ reduction in sediments.

\section{References}

Ahumada, R., A. Rudolph, and V. Martinez. 1983. Circulation and fertility of waters in Concepcion Bay. Estuarine Coastal Shelf Sci. 16: 95-105.

AlleR, R. C. 1980. Diagenetic processes near the sedimentwater interface of Long Island Sound. 2. Fe and Mn. Adv. Gcophys. 22: 351-415.

1990. Bioturbation and manganese cycling in hemipelagic sediments. Phil. Trans. R. Soc. Lond. Ser. A 331: $51-58$.

- 1994. The sedimentary Mn cycle in Long Island Sound: Its role as intermediate oxidant and the influence of bioturbation, $\mathrm{O}_{2}$, and $\mathrm{C}_{\text {org }}$ flux on diagenctic reaction balances. J. Mar. Res. 52: 259-295.

, N. E. BLAIR, Q. XIA, AND P. D. Rude. 1996. Remineralization rates, recycling, and storage of carbon in Amazon shelf sediments. Cont. Shelf Res. 16: 753-786.

Alperin, M. J., D. B. Albert, And C. S. Martens. 1994. Seasonal variation in production and consumption rates of dissolved organic carbon in an organic-rich coastal sediment. Geochim. Cosmochim. Acta 58: 4909-4930.

ANDERson, L. A., AND J. L. SARmiento. 1994. Redfield ratios of remineralization determined by nutrient data analysis. Global Biogeochem. Cycles 8: 65-80.

ARcos, D. F., AND R. E. WILsON. 1984. Upwelling and the distribution of chlorophyll $a$ within the Bay of Concepción, Chile. Estuarine Coastal Shelf Sci. 18: 25-35. 
Barnett, P. R. O., J. Watson, AND D. Conelly. 1984. A multiple corer for taking virtually undisturbed samples from shelf, bathyal, and abyssal sediments. Ocean. Acta 7: 399408.

BendeR, M. L., AND D. T. Heggie. 1984. Fate of organic carbon reaching the deep sea floor: A status report. Geochim. Cosmochim. Acta 48: 977-986.

$\longrightarrow$, AND OTHERS. 1987. A whole-core squeezer for interstitial pore-water sampling. Limnol. Oceanogr. 32: 12141225.

BERNER, R. A. 1980. Early diagenesis, a theoretical approach. Princeton.

Brandes, J. A., AND A. H. Devol. 1995. Simultaneous nitrate and oxygen respiration in coastal sediments: Evidence for discrete diagenesis. J. Mar. Res. 53: 771-797.

BRANDHORST, W. 1959. Relationship between the hake fisheries and a southerly subsurface return flow below the Perú Coastal Current off the Chilean coast. Nature 183: 18321833.

BOUDREAU, B. P. 1994. Is burial velocity a master parameter for bioturbation? Geochim. Cosmochim. Acta 58: 12431249.

- D. E. CANFIELD, AND A. MuCCI. 1992. Early diagenesis in a marine sapropel, Mangrove Lake, Bermuda. Limnol. Oceanogr. 37: 1738-1753.

Burdige, D. J., AND K. H. Nealson. 1986. Chemical and microbiological studies of sulfide-mediated manganese reduction. Geomicrobiol. J. 4: 361-387.

CANFIELD, D. E. 1988. Sulfate reduction and the diagenesis of iron in anoxic marine sediments. Ph.D. thesis, Yale Univ. $248 \mathrm{p}$.

- 1989. Reactive iron in sediments. Geochim. Cosmochim. Acta 53: 619-632.

1993. Organic matter oxidation in marine sediments, p. 333-363. In R. Wollast et al. [eds.]. Interactions of C, $\mathrm{N}, \mathrm{P}$ and $\mathrm{S}$ biogeochemical cycles. Springer.

- AND D. J. Des MARAIs. 1991. Aerobic sulfate reduction in microbial mats. Science 251: 1471-1473.

- - B. B. JøRGENSEN, AND OTHERS. 1993a. Pathways of organic carbon oxidation in three coastal sediments. Mar. Geol. 113: 27-40.

- R. RAISWELl, AND S. BotTRell. 1992. The reactivity of sedimentary iron minerals towards sulfide. Am. J. Sci. 292: 659-683.

- J. T. Westrich, C. M. Reaves, AND R. A. BERNER. 1986. The use of chromium reduction in the analysis of reduced inorganic sulfur in sediments and shales. Chem. Geol. 54: 149-155.

- B. Thamdrup, AND J. W. HANSEN. 1993 $b$. The anaerobic degradation of organic matter in Danish coastal sediments. Geochim. Cosmochim. Acta 57: 3867-3883.

Cline, J. D. 1969. Spectrophotometric determination of hydrogen sulfide in natural waters. Limnol. Oceanogr. 14: 454-458.

Crill, P. M., AND C. S. Martens. 1987. Biogeochemical cycling in an organic-rich coastal marine basin. 6. Temporal and spatial variations in sulfate reduction rates. Geochim. Cosmochim. Acta 51: 1175-1186.

Devol, A. H., AND J. P. Christensen. 1993. Benthic fluxes and nitrogen cycling in the sediments of the continental margin of the eastern North Pacific. J. Mar. Res. 51: 345372.

FISCHER, W. R. 1973. Die Wirkung von zweiwertigem Eisen auf Lösung und Umwandlung von Eisen (III)-hydroxiden, p. 37-44. In E. Schlichting and U. Schwertmann [eds.],
Pseudogley and gley: Genesis and use of hydromorphic soils. Weinheim.

Fossing, H. 1990. Sulfate reduction in shelf sediments in the upwelling reciion off central Peru. Cont. Shelf Res. 10: 355367.

- V. A. GA.LLARDO, AND OTHERS. 1995. Concentration and transpoit of nitrate by the mat-forming sulphur bacterium Thioploca. Nature 374: 713-715.

—_, AND, B. B. JøRGENSEN. 1989. Measurement of bacterial sulfate reduction in sediments: evaluation of a singlestep chromium reduction method. Biogcochemistry 8: 223 245.

Froelich, P. N., M. A. Arthur, AND others. 1988. Early diagenesis of organic matter in Peru continental margin sediments: Phosphorite precipitation. Mar. Geol. 80: 309343.

_, G. P. KinkHAMmer, AND others. 1979. Early oxidation of organic matter in pelagic sediments of the eastern equatorial Atlantic: Suboxic diagenesis. Greochim. Cosmochim. Acta 43: 1075-1090.

Gallardo, V. A. 1977. Large benthic microbial communities in sulfide bista under the Peru-Chile subsurface countercurrent. Nature 268: 331-332.

Glud, R. N., J. K GuNDERSEN, B. B. JøRGENSEN, N. P. RevSBECH, AND H. D. SCHULz. 1994. Diffusive and total oxygen uptake of deep-sea sediments in the south east Atlantic Ocean: In situ and laboratory measurements. Deep-Sea Res. 41: 1767-1788.

GOLDHABER, M. B., AND I. R. KAPLAN. 1974. The sulfur cycle, p. 569-655, In E. D. Goldberg [ed.], The sea. V. 5. Wiley.

GuNDERSEN, J. K., AND B. B. JøRGENSEN. 1991. Fine-scale in situ measurements of oxygen distribution in marine sediments. Kiel. Meeresforsch. Sonderh. 8: 376-380.

Hall, P. O. J., AlID R. C. Aller. 1992. Rapid, small-volume, flow injection analysis for $\Sigma \mathrm{CO}_{2}$ and $\mathrm{NH}_{4}{ }^{+}$in marine and freshwaters. Limnol. Oceanogr. 37: 1113-1119.

HANSEN, J. W. 1992. The ecological significance of manganese in marine serliments [in Danish]. M.S. thesis, Univ. Aarhus. $87 \mathrm{p}$.

HenRICHS, S. M. 1992. Early diagenesis of organic matter in marine sediments: Progress and perplexity, Mar. Chem. 39: 119-149.

, AND W. S. REEBURGH. 1987. Anaerobic mineralization of marine o: :ganic matter: Rates and the role of anaerobic processes in the ocean carbon economy. Geomicrobiol. J. 5: 191-237.

Hines, M. E., D. A. BAzylinski, J. B. Tugel, AND W. B. Lyons. 1991. Anatrobic microbial biogeochemistry in sediments from two bisins in the Gulf of Maine: Evidence for iron and mangarese reduction. Estuarine Coastal Shelf Sci. 32: 313-324.

HütTel, M., S. Forster, S. KIÖSER, AND H. FosSING. 1996. Overcoming, diffusive limitations: Vertical migration in the sediment-living sulfur bacterium Thioploca spp. Appl. Environ. Microbiol. 62: 1863-1872.

JONES, M. N. 1984. Nitrate reduction by shaking with cadmium. Watir Res. 18: 643-646.

JøRGENSEN, B. B. 1978. A comparison of methods for the quantification of bacterial sulfate reduction in coastal marine sediments. 1. Measurement with radiotracer techniques. Gecimicrobiol. J. 1: 11-28.

- 1982. Mineralization of organic matter in the sea bedthe role of sulfate reduction. Nature 296: 643-645.

- AND Y. COHEN. 1977. Solar Lake (Sinai). 5. The sulfur 
cycle of the benthic cyanobacterial mats. Limnol. Oceanogr. 22: 657-666.

- , AND N. P. RevsBeCH. 1989. Oxygen uptake, bacterial distribution, and carbon-nitrogen-sulfur cycling in sediments from the Baltic Sca-North sea transition. Ophelia 31: 29-49.

KeIR, R. S. 1980. The dissolution kinetics of biogenic calcium carbonate in seawater. Geochim. Cosmochim. Acta 44: 241252.

KostKa, J. E., AND G. W. Luther III. 1994. Partitioning and speciation of solid phase iron in saltmarsh sediments. Geochim. Cosmochim. Acta 58: 1701-1710.

Kristensen, E., S. I. Ahmed, ANd A. H. Devol. 1995. Aerobic and anaerobic decomposition of organic matter in marine sediment: Which is fastest? Limnol. Occanogr. 40: 14301437.

KruSE, B. 1993. Measurement of plankton $\mathrm{O}_{2}$ respiration in gas-tight plastic bags. Mar. Ecol. Prog. Ser. 94: 155-163.

LORD, C. J., III. 1980. The chemistry and cycling of iron, manganese, and sulfur in salt marsh sediments. Ph.D. thesis, Univ. Delaware.

Lovley, D. R., AND E. J. P. Phillips. 1986. Availability of ferric iron for microbial reduction in bottom sediments of the freshwater tidal Potomac River. Appl. Environ. Microbiol. 52: 751-757.

$\longrightarrow$, AND - 1987. Competitive mechanisms for inhibition of sulfate reduction and methane production in the zone of ferric iron reduction in sediments. Appl. Environ. Microbiol. 53: 2636-2641.

MACKIN, J. E., AND R. C. Aller. 1984. Ammonium adsorption in marine sediments. Limnol. Occanogr. 29: 250-257.

MaIer, S., AND V. A. Gallardo. 1984a. Description of Thioploca araucae sp. nov. and Thioploca chilea sp. nov. Int. J. Syst. Bacteriol. 34: 414-418.

- AND - 1984b. Nutritional characteristics of two marine Thioplocas determined by autoradiography. Arch. Microbiol. 139: 218-220.

Martens, C. S., AND J. V. KLump. 1984. Biogeochemical cycling in an organic rich coastal marine basin. 4. An organic carbon budget for sediments dominated by sulfate reduction and methanogenesis. Geochim. Cosmochim. Acta 48: 1987-2004.

Mehrbach, C., C. H. Culberson, J. E. Harvey, and R. M. PyTKowicz. 1973. Measurement of the apparent dissociation constants of carbonic acid in seawater at atmosphcric pressurc. Limnol. Oceanogr. 18: 897-907.

MORSE, J. 1978. Dissolution kinetics of calcium carbonate in scawater. 4: The near-equilibrium dissolution kinetics of calcium carbonate-rich decp-sea sediments. Am. J. Sci. 278: 344-355.

MuCCI, A. 1983. The solubility of calcite and aragonite in seawater at various salinities, temperatures, and one atmosphere total pressure. Am. J. Sci. 283: 780-799.

NIELSEN, L. P. 1992. Denitrification in scdiment detcrmined from nitrogen isotope pairing. FEMS Microb. Ecol. 86: 357362.

Parkes, R. J., G. R. Gibson, I. Mueller-Harvey, W. J. BUCKINGHAM, AND R. A. HERBERT. 1989. Determination of the substrates for sulphate-reducing bacteria within marine and estuarine sediments with different rates of sulphate reduction. J. Gen. Microbiol. 135: 175-187.

PETERSON, W. T., AND OTHERS. 1988. The nearshore zone during coastal upwelling: Daily variability between primary and secondary production off central Chile. Prog. Occanogr. 20: $1-40$.
Phillips, E. J. P., AND D. R. Lovley. 1987. Determination of $\mathrm{Fc}(\mathrm{III})$ and $\mathrm{Fe}(\mathrm{II})$ in oxalate extracts of sediments. Soil Sci. Soc. Am. J. 51: 938-941.

PostMA, D. 1985. Concentration of $\mathrm{Mn}$ and separation from Fe in sediments-1. Kinetics and stoichiometry of the reaction between birnessite and dissolved $\mathrm{Fe}(\mathrm{II})$ at $10^{\circ} \mathrm{C}$. Geochim. Cosmochim. Acta 49: 1023-1033.

Pyzik, A. J., AND S. E. Sommer. 1981. Sedimentary iron monosulfides: Kinetics and mechanism of formation. Geochim. Cosmochim. Acta 45: 687-698.

Raiswell, R., D. E. Canfield, AND R. A. Berner. 1994. A comparison of iron extraction methods for the determination of degree of pyritization and the recognition of ironlimited pyrite formation. Chem. Geol. 111: 101-110.

RedField, A. C., B. H. Ketchum, AND F. A. Richards. 1963. The influence of organisms on the composition of sea-water, p. 26-77. In M. N. Hill [ed.], The sea. V. 2. Wiley Interscience.

Reimers, C. E., R. A. JahNKe, AND D. C. MCCorkle. 1992. Carbon fluxes and burial rates over the continental slope and rise off central California with implications for the global carbon cycle. Global Biogcochem. Cycles 6: 199224.

ROA, R., AND OTHERs. 1995. Nursery ground, age structure and abundance of juvenile squat lobster Pleuroncodes monodon on the continental shelf off central Chile. Mar. Ecol. Prog. Scr. 116: 47-54.

Rosenfeld, J. K. 1979. Ammonium adsorption in ncarshore anoxic sediments. Limnol. Occanogr. 24: 356-364.

Schink, B. 1988. Principles and limits of anaerobic degradation: Environmental and technological aspects p. 771846. In A. J. B. Zehnder [ed.], Biology of anaerobic microorganisms. Wiley.

Schulz, H. 1995. Zur Struktur der Thioploca-Gemeinschaft auf dem Schelf vor Concepción/Chile. M.S. thesis, Univ. Bremen. 69 p.

- B. B. JøRgensen, H. Fossing, AND N. B. RAMsing. 1996. Community structure of filamentous, sheath-building sulfur bacteria, Thioploca spp., off the coast of Chile. Appl. Environ. Microbiol. 62: 1855-1862.

SChWERTMANN, U. 1964. Differenzierung der Eisenoxide des Bodens durch Extraktion mit Ammoniumoxalat-Lösung. Z. Pflanzen. Bodenk. 105: 194-202.

Seitzinger, S. P., S. W. Nixon, And M. E. Q. Pilson. 1984. Denitrification and nitrous oxide production in a coastal marine ecosystem. Limnol. Oceanogr. 29: 73-83.

SobArzo, M. A. 1994. Occanografia fisica entre Punta Nugurne $\left(35^{\circ} 57^{\prime} \mathrm{S} ; 72^{\circ} 47^{\prime} \mathrm{W}\right)$ y Punta Manuel $\left(38^{\circ} 30^{\prime} \mathrm{S}\right.$; $\left.73^{\circ} 31^{\prime} \mathrm{W}\right)$, Chile: Una revision historica (1936-1990). Gayana Oceanol, 2: 5-17.

Sørensen, J. 1978. Denitrification rates in a marine sediment as measured by the acetylene inhibition technique. Appl. Environ. Microbiol. 43: 319-324.

-1982. Reduction of ferric iron in anacrobic, marine sediment and interaction with reduction of nitrate and sulfate. Appl. Environ. Microbiol. 43: 319-324.

- D. Christensen, AND B. B. JøRGENSEN. 1981. Volatile fatty acids and hydrogen as substrates for sulfate-reducing bacteria in anaerobic marine sediments. Appl. Environ. Microbiol. 42: 5-11.

- - AND B. B. JøRGENSEN. 1987. Early diagenesis in sediments from Danish coastal waters: Microbial activity and $\mathrm{Mn}-\mathrm{Fe}-\mathrm{S}$ geochemistry. Gcochim. Cosmochim. Acta 51: 1583-1590. 
AND N. P. REVSBeCH. 1979. A comparison of oxygen, nitrate, and sulfatc respiration in coastal marine sediments. Microb. Ecol. 5: 105-116.

Stookey, L. L. 1970. Ferrozine-a new spectrophotometric reagent for iron. Anal. Chem. 42: 779-781.

Straub, K. L., M. Benz, B. Schink, AND F. Widdel. 1996. Anaerobic, nitrate-dependent microbial oxidation of fcrrous iron. Appl. Environ. Microbiol. 62: 1458-1460.

Suter, D., C. Siffert, B. Sulzberger, ANd W. Stumm. 1988. Catalytic dissolution of iron(III) (hydr)oxides by oxalic acid in the presence of Fe(II). Naturwissenschaften 75: 571-573.

Teske, A., N. B. Ramsing, J. Küver, AND H. Fossing. 1996. Phylogeny of Thioploca and related filamentous sulfideoxidizing bacteria. Syst. Appl. Microbiol. 18: 517-526.

Thamdrup, B., H. Fossing, AND B. B. JoRGENSEN. 1994a. Manganese, iron, and sulfur cycling in a coastal marine sediment, Aarhus Bay, Denmark. Geochim. Cosmochim. Acta 58: 5115-5129.
R. N. Clud, AND J. W. Hansen. 1994b. Manganese oxidation and in situ manganese fluxes from a coastal sediment. Geo him. Cosmochim. Acta 58: 2563-2570.

WESTRICH, J. T. 1983. The consequences and controls of bacterial sulfate reduction in marine sediments. Ph.D. thesis, Yale Univ.

, AND R. A. BERNER. 1984. The rolc of sedimentary organic matter in bactcrial sulfate reduction: The $G$ model tested. Limiol. Oceanogr. 29: 236-249.

ZhABINA, N. N., AND I. I. VolKov. 1978. A method of determination of various sulfur compounds in sea sediments and rocks, p. 735-746. In W. E. Krumbein [cd.], Environmental biogeochemistry and geomicrobiology. V. 3. Ann Arbor Sci.

Submitted: 22 January 1996 Accepted: 2 April 1996 Amended: 12 June 1996 